\title{
MicroRNA-7, synergizes with RORa, negatively controls the pathology of brain tissue inflammation
}

Dongxu Yue ${ }^{1,2+}$, Juanjuan Zhao ${ }^{1,2 \dagger}$, Huizi Chen ${ }^{1,2}$, Mengmeng Guo ${ }^{1,2}$, Chao Chen ${ }^{1,2}$, Ya Zhou ${ }^{1,3}$ and Lin Xu ${ }^{1,2^{*}}$

\begin{abstract}
Background: Accumulating evidence has documented that microRNA-7 (miR-7) plays an important role in the pathology of various diseases. However, the potential role of miR-7 in brain tissue inflammation (BTI) remains unclear.

Methods: We detected the expression of miR-7 in LPS-induced murine BTI model and observed the possible effects of miR-7 deficiency on the pathology of BTI. To elucidate the mechanism, the target gene of miR-7 was screened out by Gene chip assay and its potential roles in BTI were evaluated by Western blot, immunofluorescence, and RNAi assay, respectively.
\end{abstract}

Results: MiR-7 was upregulated in brain tissue in BTI mice and its deficiency could significantly aggravate the pathology of brain tissue. Moreover, RORa, a new target molecule of miR-7, was upregulated in brain tissue from miR-7 deficiency BTI mice. Of note, downregulation of RORa could remarkably exacerbate the pathology of brain tissue and elevate the transduction of NF-KB and ERK1/2 signaling pathways in brain tissue from miR-7 deficiency BTI mice. Furthermore, RORa and miR-7 were dominantly co-expressed in neurons of BTI mice. Finally, RORa synergized with miR-7 to control the inflammatory reaction of neuronal cells in response to LPS stimulation.

Conclusions: MiR-7 expression is upregulated in BTI model. Moreover, miR-7 synergizes with its target gene RORa to control the inflammation reaction of neurons, thereby orchestrating the pathology of BTI.

Keywords: miR-7, Brain tissue inflammation, Neuron, NF-KB, RORa, RNA interference

\section{Background}

Brain tissue inflammation (BTI), a complicated process including a series of integrated steps, is closely related to the occurrence and development of various brain diseases [1-3]. Up to now, the underlying mechanism of pathology of BTI remains elusive. Recent evidence has shown that microRNAs (miRNAs), small endogenous RNAs of 21-25 nucleotides capable of guiding the posttranscriptional silencing of their target mRNAs through base pairing encompassing mature mRNA 3'-untranslated region $\left(3^{\prime}-\mathrm{UTR}\right)$, play essential regulatory roles in

\footnotetext{
* Correspondence: xulinzhouya@163.com

${ }^{\dagger}$ Dongxu Yue and Juanjuan Zhao contributed equally to this work.

'Special Key Laboratory of Gene Detection \& Therapy of Guizhou Province,

Zunyi 563099, Guizhou, China

²Department of Immunology, Zunyi Medical University, Zunyi 563099,

Guizhou, China

Full list of author information is available at the end of the article
}

the development of BTI [4-6]. For instance, miR-126 is implicated in brain vascular inflammation and intracerebroventricular (I.C.V) administration of miR-126-3p mimic can significantly suppress the upregulation of phosphoinositide-3-kinase regulatory subunit 2 , as well as reduce blood-brain barrier permeability and brain edema [7]. Moreover, Peli1 is an important E3 ubiquitin-protein ligase contributing to neuroinflammation. MiR-142a-3p and miR-155-5p can directly suppress Peli1 expression and protect against the inflammatory effects of METH treatment partially through activating p38 MAPK and NF- $\mathrm{KB}$ inflammatory pathways [8]. These studies indicate that miRNAs might be potential candidates for therapy against BTI. Therefore, further investigation on the possible roles of distinct miRNA molecules in the development of BTI will not only benefit to the understanding on pathology of BTI, but also be 
valuable for the development of novel therapeutic strategies against brain diseases.

MicroRNA-7 (miR-7) was first identified by LagosQuintana in 2001 [9] and has been reported to regulate the biology of various tumor cells and the development of inflammation diseases by repressing the expression of different target molecules [10, 11]. For instance, Fan et al. found that miR-7 suppressed angiogenesis of colorectal cancer cells through ERK signaling by downregulation epidermal growth factor receptor [12]. Moreover, Ye et al. reported that miR-7 deficiency promoted p65mediated aberrant NF- $\mathrm{KB}$ activation to facilitate gastric cancers metastasis and ultimately resulted in the worse clinical outcome in human gastric cancer [13]. Our previous study also showed that miR-7 regulated TLR9 signaling and affected the growth and metastatic potential of human lung cancer cells [14]. Importantly, many recent studies have reported that miR-7 is dominantly expressed in brain tissue and involved in the biological functions of brain [15-17]. Moreover, miR-7 also plays an important role in the development of brain diseases [18-20]. For example, Chen et al. reported that miR-7 was closely related to the differentiation of neural stem cells and the development of the cerebral cortex [21]. Moreover, Kabaria et al. found that miR-7 exerted a cytoprotective effect by elevating the expression level of Nrf2 through inhibiting Keap1 expression [22]. However, the exact role of miR-7 involved in the development of BTI has yet to be fully elucidated.

To this aim, in the present study, we analyzed the expression level of miR-7 in LPS-induced murine BTI model and observed the possible influence of miR-7 deficiency on the pathology of BTI. We found that miR-7 was upregulated in brain tissue in BTI model and its deficiency could significantly aggravate the development of brain inflammation. Moreover, $\mathrm{ROR} \alpha$, a new target molecule of miR-7, was upregulated in brain tissue from miR-7 deficiency BTI mice. Of note, we found that downregulation of $R O R \alpha$ could remarkably exacerbate the pathology of brain tissue, accompanied by elevated transduction of NF- $\mathrm{KB}$ and ERK1/2 signaling pathways in miR-7 deficiency BTI mice. Thus, our data suggested a novel network model in which miR-7 synergizes with, but not antagonizes, its target gene ROR $\alpha$ to control the pathology of BTI, which could ultimately aid the understanding of the pathogenesis of BTI and the development of new therapeutic strategies against clinical inflammatory brain diseases.

\section{Materials and methods}

\section{Mice}

C57BL/6 wild-type (WT) mice and C57BL/6 background miR-7 deficiency (miR-7 ${ }^{\text {def }}$ ) mice (both $8-10$ weeks of age) were housed under specific pathogen-free (SPF) conditions at Zunyi Medical University [23].

\section{LPS-induced murine BTI model}

WT mice andmiR-7 $7^{\text {def }}$ mice were intraperitoneally injected with LPS $(2.5 \mathrm{mg} / \mathrm{kg}$ of body weight, Escherichia coli 0111: B4; Sigma) and control group with vehicle (PBS) [24]. After $12 \mathrm{~h}$, the brain tissue was collected.

\section{Histopathology}

Brain tissue was fixed in $4 \%(\mathrm{w} / \mathrm{v})$ paraformaldehyde, followed by routine dehydration and embedded in paraffin, and cut into $4 \mu \mathrm{m}$ thick. Then, slices were subjected to xylene dewaxing, gradient ethanol dehydration, routine hematoxylin-eosin staining (H\&E), and again dehydrated with gradient ethanol, followed by xylene transparency and mounting. Pathological changes in brain tissue were observed under a light microscope (Olympus, Tokyo, Japan). Two investigators blinded to group assignments analyzed the samples and determined levels of brain inflammation injury.

\section{Quantitative real-time PCR analysis}

For miR-7 expression analysis, cDNA was synthesized by TaqMan MicroRNA Reverse Transcription Kit (ThermoFisher Scientific) using S1000TM Thermal cycler PCR Amplifier (Bio-Rad). Next, real-time PCR was performed to quantify miR-7 expression by miR-7 probe of TaqMan (Life Technologies) according to the instructions of the manufacturer using C1000TM Thermal cycler Quantitative Real-time PCR Amplifier (Bio-Rad). U6 as endogenous control was used for normalization. For mRNA analysis, cDNA was synthesized using a Prime Script RT reagent kit (Takara, Kusatsu, Japan) according to the manufacturer's instructions. Real-time PCR was carried out by SYBR Premix Ex Taq II (Takara, Kusatsu, Japan) according to the instructions of the manufacturer. GAPDH as endogenous control was used for normalization. The relative expression levels of miR-7 and mRNAs were determined using the standard $2^{-\Delta \Delta C T}$ (cycle threshold) method. The sequences of the primers used for real-time PCR were shown in Table 1.

\section{Fluorescence in situ hybridization (FISH)}

To evaluate the cellular distribution of pre-miR-7-2 in the brain, FISH assay was performed based as our previous description with some modifications [23]. Briefly, before hybridization incubation, all solutions were prepared with diethylpyrocarbonate-treated water. After deparaffinization and rehydration, tissue sections were treated by pepsin digestion. Sections were next incubated or heated in the microwave, and then were incubated with hybridization cocktail containing miR-7-2 probe (1:1000; EXIQON; no. $38485-01)$ at $42^{\circ} \mathrm{C}$ for 
Table 1 The primer sequence used for real-time quantitative PCR

\begin{tabular}{|c|c|}
\hline Gene & Primer sequence $\left(5^{\prime}-3^{\prime}\right)$ \\
\hline \multirow[t]{2}{*}{ TGF- $\beta$} & F: CCCCATTCCTACTTCTCC \\
\hline & R: ACGCACCTTTCTGGTTACAC \\
\hline \multirow[t]{2}{*}{ IL-6 } & F: AGACAAAGCCAGAGTCCTTCAG \\
\hline & R: GGTCTTGGTCCTTAGCCACTC \\
\hline \multirow[t]{2}{*}{ TNF-a } & F: TGTCTACTGAACTTCGGGGTG \\
\hline & R: CTGCTCCTCCACTTGGTGGTT \\
\hline \multirow[t]{2}{*}{$I L-1 \beta$} & F: GAGCTTCAGGCAGGCAGTAT \\
\hline & R: TTGTTCATCTCGGAGCCTGTA \\
\hline \multirow[t]{2}{*}{ TROVE2 } & F: GAAGTGTGTCGCATTCCGACC \\
\hline & R: GGACAGTCGGAGGAGATCTTT \\
\hline \multirow[t]{2}{*}{ RORa } & F: GGAGACAAATCGTCAGGAATC \\
\hline & R: ACCAAACTTGACAGCATCTCG \\
\hline \multirow[t]{2}{*}{ Col4a3bp } & F: TTGAAGCTGCTCTTGACAGAC \\
\hline & R: TCTATGCGTCCCGACAGAAGA \\
\hline \multirow[t]{2}{*}{ Gpr158 } & F: AATTAGAAGCAGCCCAATGG \\
\hline & R: TTCACGAACAGCACAAAGAA \\
\hline \multirow[t]{2}{*}{ Zfp212 } & F: ACCAAGTCACCCACCATCTCT \\
\hline & R: GAGAACCTGCTTCGAAACAA \\
\hline \multirow[t]{2}{*}{ Socs4 } & F: CCCCAGTGCCTGTATGTTCTT \\
\hline & R: CTGCTGCTCTGGCACATCAAT \\
\hline \multirow[t]{2}{*}{$\mathrm{C} 2 \mathrm{~cd} 2$} & F: TCAGGCCTTAGCCATGTGT \\
\hline & R: CGTGGGGACTTGAGTTCA \\
\hline \multirow[t]{2}{*}{ Syt4 } & F: GAGAAGCTGGGGACACTCTT \\
\hline & R: ACGGGTCAGAGGTCATGGATT \\
\hline \multirow[t]{2}{*}{ Spock3 } & F: CAGTCTGTGGTTCTGATGGGC \\
\hline & R: GACTTATCGGAGGGACATGG \\
\hline \multirow[t]{2}{*}{ Gpr22 } & F: GCAAAACACCAACTGCTCCAA \\
\hline & R: ACTGCATGTTGATTTCCAGAA \\
\hline \multirow[t]{2}{*}{ Basp1 } & F: CTCTTTGACGGCCACGCTTTG \\
\hline & R: CTGAGCAAGAAGAAGAAGGGCT \\
\hline \multirow[t]{2}{*}{ Tmed5 } & F: TCGATCTCCAACGATGCCTT \\
\hline & R: TCACACCCTCTITGGACAGTG \\
\hline \multirow[t]{2}{*}{ Ptprj } & F: TGCCATTTGCATTGCTCCAG \\
\hline & R: CTTAAGCCCAGGCACTTCGT \\
\hline \multirow[t]{2}{*}{ Zfp606 } & F: TCATGGACCAGTCTTGGGGG \\
\hline & R: ATCTCACCTCGACTTGGGCTA \\
\hline \multirow[t]{2}{*}{ Aqp11 } & F: TGCAGGAATCCCATCCACAC \\
\hline & R: CCCTCCTGCATAGGCCAAAA \\
\hline \multirow[t]{2}{*}{ 1110059G10Rik } & F: TCTTCAGCTGTTAGGTCTCCC \\
\hline & R: GAGCAAGCGGAACCAAGTGT \\
\hline \multirow[t]{2}{*}{ Gtdc1 } & F: CACCCTTCTGTGTGGAGCTGA \\
\hline & R: TTACGGGGTAAGTAGCCCCA \\
\hline GAPDH & F: GAAGGTCGGAGTCAACGGATT \\
\hline
\end{tabular}

Table 1 The primer sequence used for real-time quantitative PCR (Continued)

\begin{tabular}{ll}
\hline Gene & Primer sequence (5'-3') \\
\hline miR-7 & R: ATGGGTGGAATCATATTGGAA \\
U6 & F: CGGCGGTGGAAGACTAGTGATT \\
Common reverse & F: AGAGAAGATTAGCATGGCCCCTG \\
\hline
\end{tabular}

Note: TROVE2 TROVE domain family, member 2; RORa RAR-related orphan receptor alpha; Col4a3bp collagen, type IV, alpha 3 (Goodpasture antigen) binding protein; Gpr158 G protein-coupled receptor 158; Zfp212 Zinc finger protein 212; Socs 4 suppressor of cytokine signaling 4; $C 2 c d 2 \mathrm{C} 2$ calciumdependent domain containing 2; Syt4 synaptotagmin IV; Spock3 sparc/ osteonectin, cwcv and kazal-like domains proteoglycan 3; Gpr22 G proteincoupled receptor 22; Basp 1 brain abundant, membrane attached signal protein 1; Tmed5 transmembrane emp24 protein transport domain containing 5; Ptprj protein tyrosine phosphatase, receptor type, J; Zfp606 zinc finger protein 606; 1110059G10Rik RIKEN CDNA 1110059G10 gene; Gtdc1 glycosyltransferase-like domain containing $1 ; F$ forward primer; $R$ Reverse primer

overnight. Next, the sections were washed in PBS and incubated with a secondary antibody of $\mathrm{Cy} 3$ conjugated goat-anti-rabbit IgG (1:250; Invitrogen) in the dark, at room temperature for $1 \mathrm{~h}$. Then, the slides were rinsed with PBS-T three times, for $5 \mathrm{~min}$ each and counterstained, mounted with Slow Fade Gold Antifade Reagent with DAPI (1:1000) in the dark, at room temperature for $10 \mathrm{~min}$, before examination by fluorescence microscopy (Zeiss Axioplan 2).

\section{Enzyme-linked immunosorbent assay (ELISA)}

The brain tissue was homogenized in $100 \mathrm{mg} / \mathrm{mL}$ cold PBS. The samples were centrifuged at $14,000 \times g$ for 15 min. The brain tissue supernatant or neuronal PC12 cells culture supernatant was collected for a protein assay using a BCA protein assay reagent kit (Solarbio, Beijing, China). The concentration of IL-1 $\beta$, IL-6, TNF$\alpha$, and TGF- $\beta$ were determined using Quantikine Immunoassay kit (eBioscience) according to the manufacturer's instructions, respectively. The ELISA results were normalized to total protein concentration.

\section{Multiplexed fluorescent immunohistochemical staining} According to Opal protocol of multiplexed fluorescent staining, slides were deparaffinized in xylene and rehydrated in ethanol. Antigen retrieval was performed in 10 $\mathrm{mmol} / \mathrm{L}$ citric acid buffer ( $\mathrm{pH}$ 6.0) for $10 \mathrm{~min}$ using a $750-\mathrm{W}$ microwave and rinsed with PBS-T three times, for $5 \mathrm{~min}$ each, slides were blocked with $10 \%$ normal goat serum at room temperature for $30 \mathrm{~min}$ and then, incubated with rabbit anti-mouse ROR $\alpha$ antibody (1:400; Abcam; no. ab60134) overnight at $4{ }^{\circ} \mathrm{C}$. After the overnight incubation, slides were rinsed with PBS- $\mathrm{T}$ three times and incubated with Goat anti-Rabbit IgG H\&L (HRP) secondary antibody (1:1000 dilution; Abcam; no. ab6721) at room temperature for $1 \mathrm{~h}$. Later, ROR $\alpha$ was visualized using PPD520 tyramine signal amplification 
Plus (1:100). Subsequently, slides were placed in citrate buffer (pH 6.0) and subjected to microwave again, and then incubated with primary rabbit antibodies for IBA-1 (1:1000 dilution; Abcam; no. ab178847) in a humidified chamber at room temperature for $1 \mathrm{~h}$. After incubating with Goat Anti-Rabbit IgG H\&L (HRP) secondary antibody for $1 \mathrm{~h}$. IBA-1 was then visualized using PPD570 tyramine signal amplification. After washing in PBS three times, sections were counterstained, mounted with Slow Fade Gold Antifade Reagent with DAPI, and left for $10 \mathrm{~min}$ in the dark at room temperature before examination by fluorescence microscopy.

\section{RORa RNAi transfer experiments in vivo}

According to previous reports [25-27], the stereotaxic coordinates were $0.8 \mathrm{~mm}$ posterior, $1.2 \mathrm{~mm}$ lateral to the bregma, and $3 \mathrm{~mm}$ ventral to the surface of the skull. Twelve mice were divided randomly into two groups ( $n=6$ per group), $5 \mu \mathrm{L}$ ROR $\alpha$ siRNA or negative control (NC) siRNA was diluted with the same volume of transfection reagent in vitro (Invivofectamine 3.0; ThermoFisher, Scientific). After mixing gently, the solution was I.C.V. through a micro syringe according to the guidance of stereotaxic instrument (Kent Scientific Co., Torrington, CT, USA) under anesthetized.

\section{Cell culture}

Neuronal PC12 cells and human embryonic kidney cell line HEK 293T cells (saved in our lab) were cultured in completed Roswell Park Memorial Institute (RPMI-1640; GIBCO) medium containing 10\% (v/v) FBS, penicillin $(100 \mathrm{IU} / \mathrm{mL})$, and streptomycin $(100 \mu \mathrm{g} / \mathrm{mL})$ on $100-\mathrm{mm}$ dishes at $37^{\circ} \mathrm{C}$ under $5 \%$ $\mathrm{CO}_{2}$ humidified atmosphere.

\section{Plasmid construction and luciferase reporter assay}

The luciferase reporter assay was performed to determine whether ROR $\alpha$ (Gene ID, 1988338) was a direct target of miR-7. The possible sites (1806 bp-1812 bp segment, ACTTGTT) of binding between ROR $\alpha 3^{\prime}$ UTR and miR-7 were predicted using miRDB database (http://www.mirdb.org). A fragment of $200 \mathrm{bp}$ containing wild-type ROR $\alpha$ 3'-UTR (5'-ACTTGTT-3') or a random mutation sequence of mutant ROR $\alpha 3^{\prime}$-UTR (5'-GTCCACC-3') was directly synthesized (Sangon, Shanghai, China). Two fragments were ligated to pEZXFR02 reporter vector (GeneCopoeia, Rockville, MA, USA), respectively. Then, the wild-type (ROR $\alpha 3^{\prime}$-UTR WT) or mutant reporter vector (ROR $\alpha 3^{\prime}$-UTR MUT) was co-transfected into HEK-293T cells in 12-well plates with $100 \mathrm{~nm}$ miR-7 mimics or negative control (NC) mimics by Lipofectamine 3000 (Invitrogen), respectively. After $48 \mathrm{~h}$, cells were lysed and subjected to luciferase assays using the Dual Luciferase Reporter Assay System (Promega).

\section{Tissue immunohistochemistry (IHC)}

Immunohistochemical staining was done using the SP method (universal immunohistochemical staining kit, Zhong-shan Golden Bridge BioTechnology Beijing, China). Slices were subjected to xylene dewaxing and gradient ethanol dehydration. Antigen retrieval was performed in 10-mmol/L citric acid buffer ( $\mathrm{pH}$ 6.0) for 10 min using a 750-W microwave and incubated with $3 \%$ (v/v) methanol-hydrogen peroxide to block endogenous peroxidases at room temperature for $15 \mathrm{~min}$. Next, slices were incubated with rabbit anti-mouse antibodies at appropriate dilution in TBST overnight at $4{ }^{\circ} \mathrm{C}$. The primary antibodies used were as follows: IBA-1 (1: 8000; Abcam; no. ab178847), GFAP (1:500; Abcam; no. ab68428), NeuN (1:1000; Abcam; no. ab177487), ROR $\alpha$ (1:1000; Abcam; no. ab60134), and NF-kB (1: 1000; Abcam; no. ab32536). PBS instead of primary antibody served as a control. Slices were rinsed with PBS-T three times and incubated with Goat AntiRabbit IgG H\&L (HRP) secondary antibody (1:1000; Abcam; no. ab6721) at room temperature for $1 \mathrm{~h}$. Finally, slices were incubated with streptavidin-biotin protein and peroxidase (1:200) and counterstained with hematoxylin before observed under a light microscope.

\section{Western blotting analysis}

After brain tissue was homogenates, total protein was extracted, and protein concentration was quantified using the BCA Protein Quantitation Kit. Total protein was mixed with $5 \times$ SDS protein sample buffer solution (4:1) and heated at $100{ }^{\circ} \mathrm{C}$ for $10 \mathrm{~min}$ and stored at $20^{\circ} \mathrm{C}$. Protein samples were subjected to SDS-PAGE and transferred to polyvinylidene difluoride (PVDF) membranes (Bio-Rad). The membranes were blocked with 5\% skim milk in PBS plus 0.05\% Tween 20 (PBS-T) at room temperature for $90 \mathrm{~min}$, and then incubated with rabbit anti-mouse antibodies at appropriate dilution in TBST overnight at $4{ }^{\circ} \mathrm{C}$. The primary antibodies used were as follows: ROR $\alpha$ (1:1000; Abcam; no. ab60134), NF-кB (1:1000; Cell Signaling Technology; no. 4764), phosNF-кB (1:1000; Cell Signaling Technology; no. 3039), ERK (1:1000; Cell Signaling Technology; no. 4695), phos-ERK (1:1000; Cell Signaling Technology; no. 4370), AKT (1:1000; Cell Signaling Technology; no. 4691), phos-AKT (1:1000; Cell Signaling Technology; no. 4060), and GAPDH (1:5000; Abcam; no. ab8245). PBS instead of primary antibody served as a control. After overnight incubation, the membrane was rinsed with PBS-T three times and incubated with Goat Anti-Rabbit IgG H\&L (HRP) secondary antibody (1: 

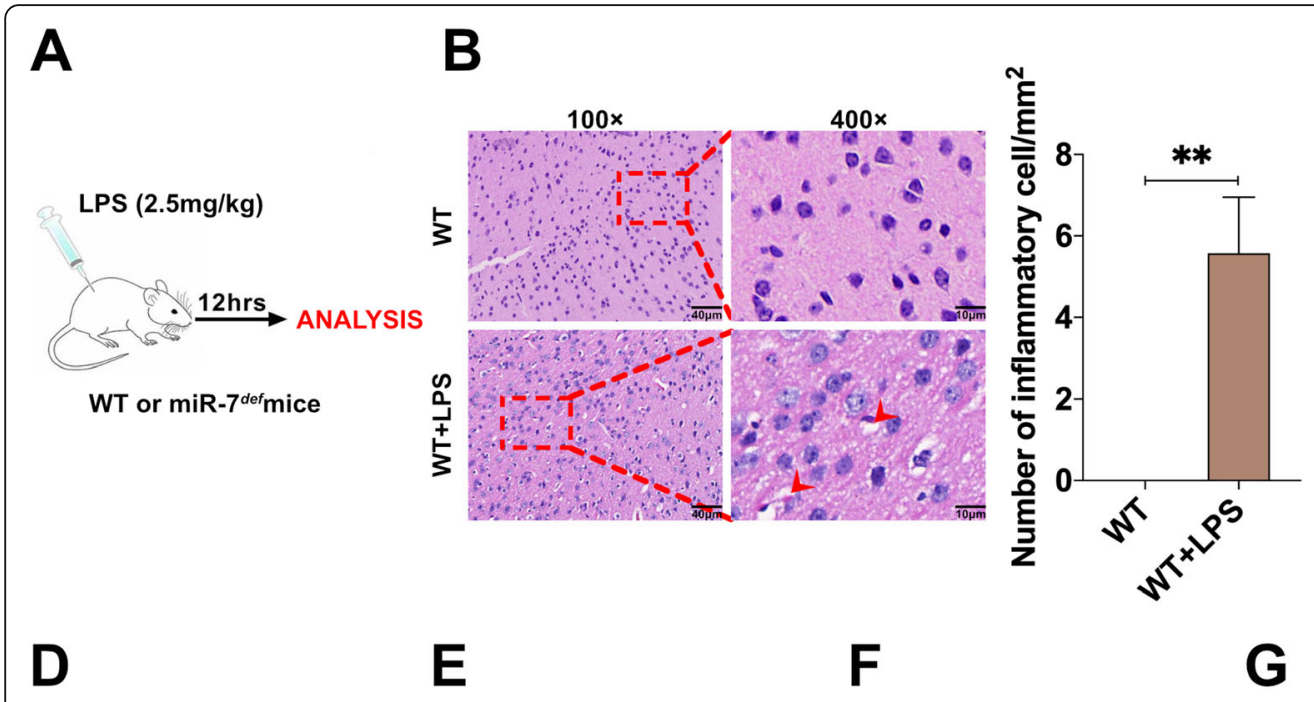

C
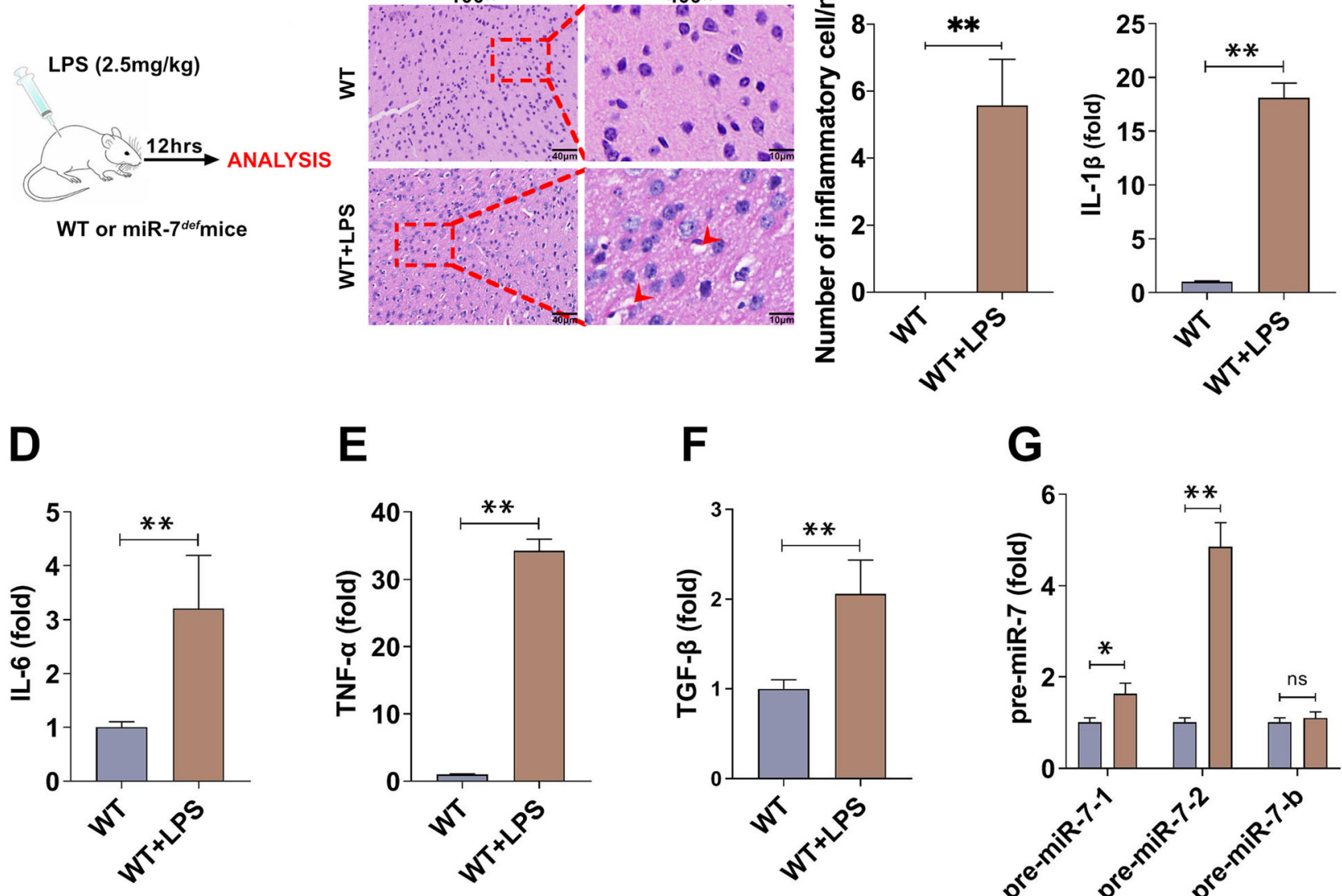

\section{H}
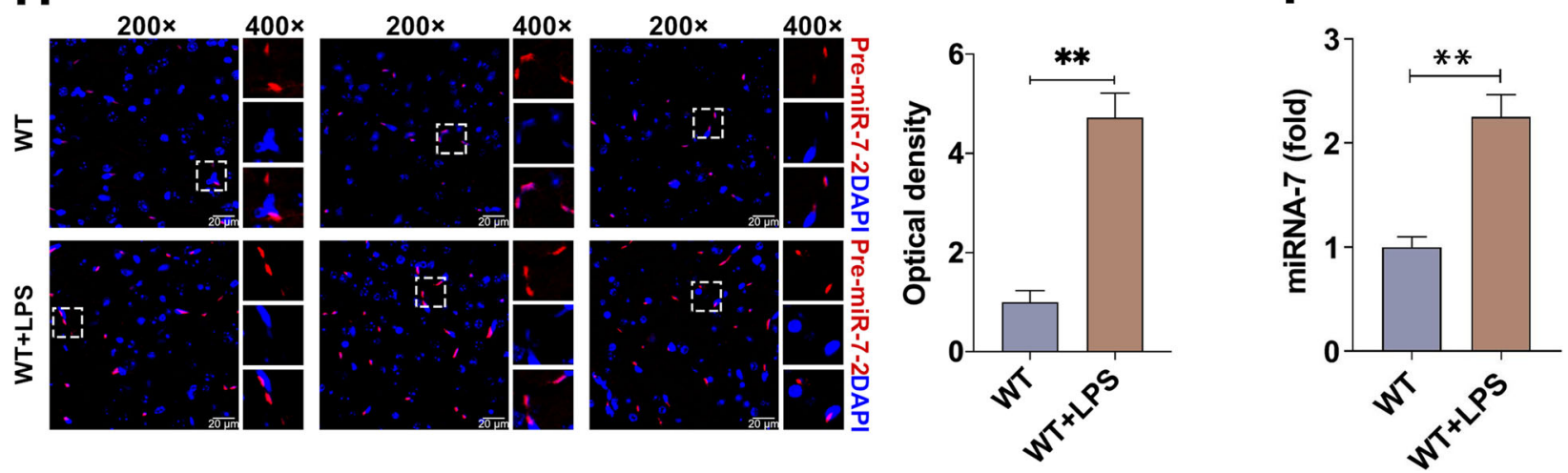

Fig. 1 The expression of miR-7 is upregulated in BTI model. a Schematic representation of the animal experiments. $\mathbf{b}$ WT mice ( $n=6$ per group) were intraperitoneally injected with LPS ( $2.5 \mathrm{mg} / \mathrm{kg}$ of body weight) and control group with PBS. After $12 \mathrm{~h}$, the pathology of brain tissue was observed by H\&E staining ( $n=3$ per group; arrows indicate hemorrhage foci). c-f The relative expression levels of cytokines (IL-1 $\beta$, IL-6, TNF-a, and TGF- $\beta$ ) were detected by real-time PCR assay and calculated ( $n=6$ per group; $t$ test). $\mathbf{g}$ The expression levels of pre-miR-7-1, pre-miR-7-2, and pre-miR-7-b in brain tissue were determined by real-time PCR assay and calculated ( $n=6$ per group; $t$ test). $\mathbf{h}$ The expression level of pre-miR-7-2 in brain tissue was determined by FISH ( $n=3$ per group). $\mathbf{i}$ The relative expression of mature miR-7 in brain tissue was analyzed by real-time PCR assay and calculated $\left(n=6\right.$ per group, $\left.{ }^{*} P<0.05, * * P<0.01\right)$ 
2000; Abcam; no. ab6721) at room temperature for 1 h. Finally, the signals were determined by chemiluminescence image system (Bio-Rad).

\section{Immunofluorescence (IF)}

Sections were hydrated and rinsed with PBS three times, for $5 \mathrm{~min}$ each, then blocked with $10 \%$ normal goat serum at room temperature for $30 \mathrm{~min}$ and incubated with rabbit anti-mouse antibodies at appropriate dilution in TBST overnight at $4{ }^{\circ} \mathrm{C}$. The primary antibodies used were as follows: $\operatorname{ROR} \alpha$ (1:100; Abcam; no. ab60134), NeuN (1:100; Abcam; no. ab177487), and GFAP (1:100; Cell Signaling Technology; no. 80788). PBS instead of primary antibody served as a control. Then, slices were rinsed with cold PBS three times, for $5 \mathrm{~min}$ each, and incubated with a

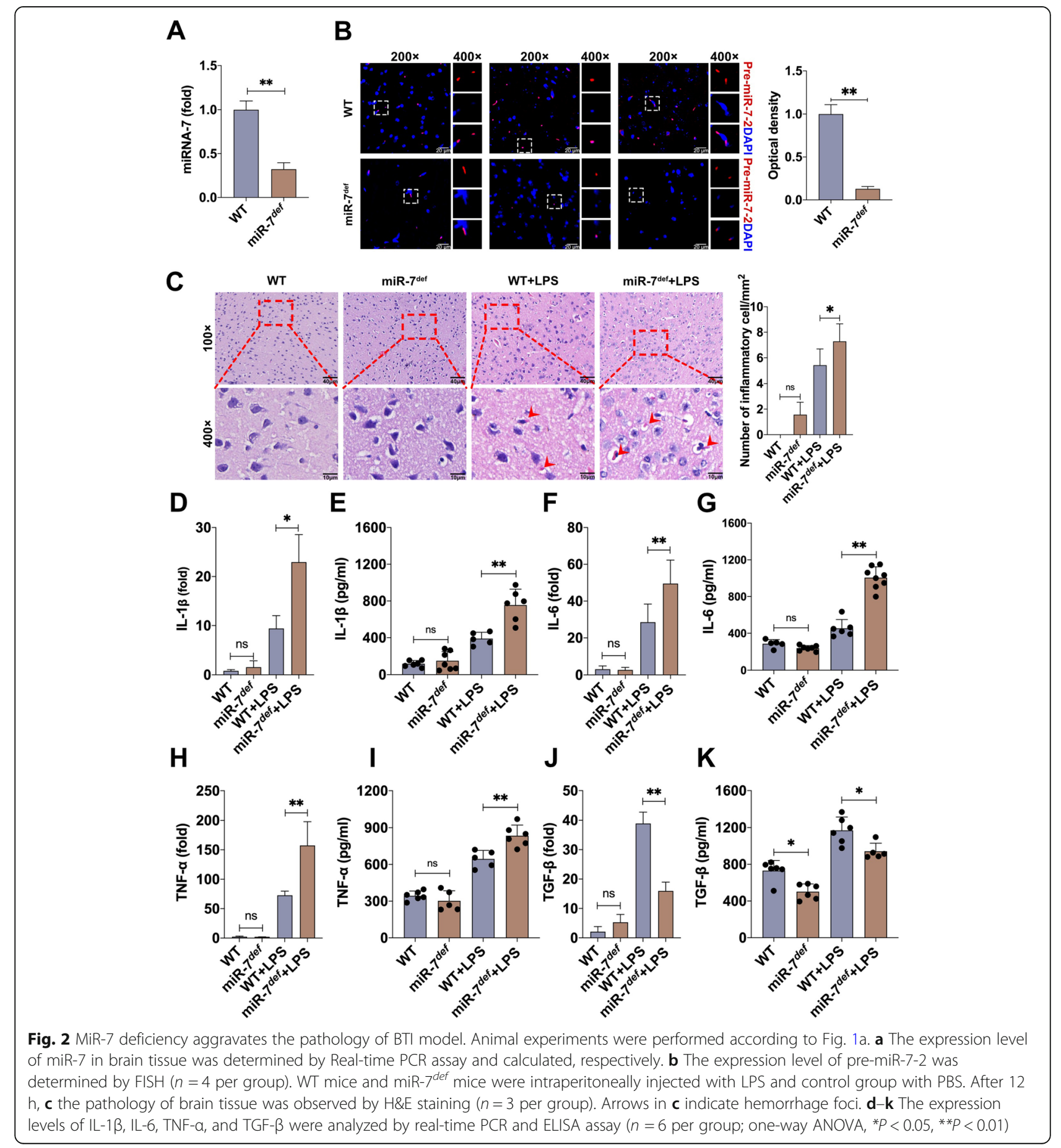




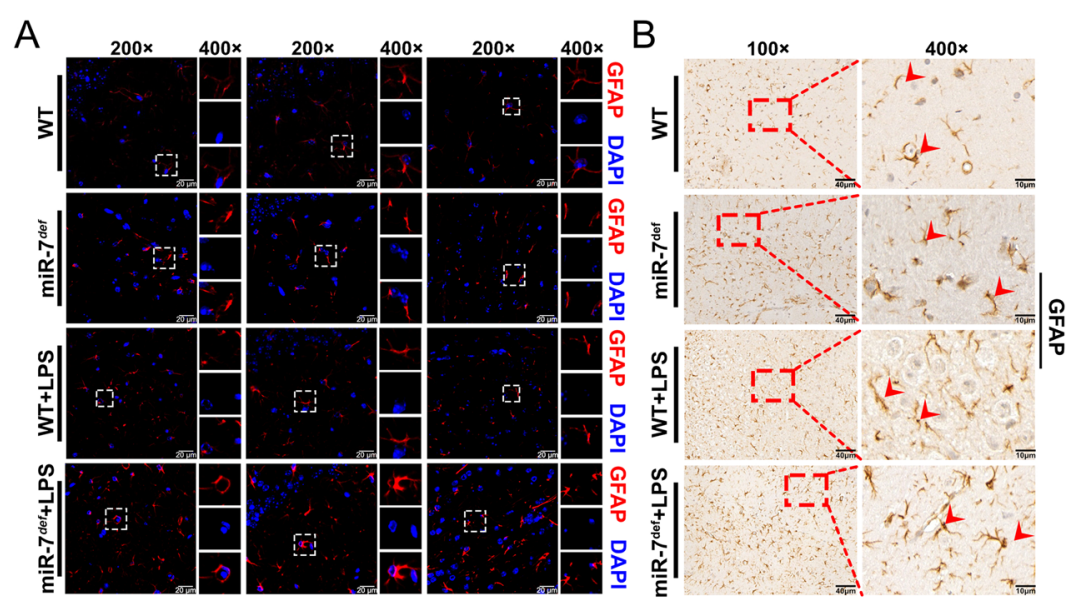

C
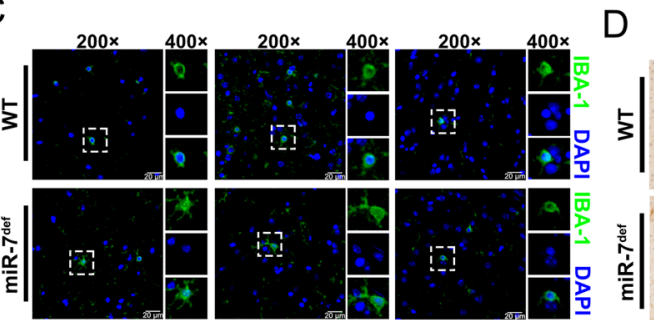

$100 x$

$400 x$
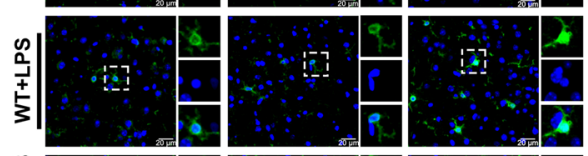

$\left|\begin{array}{ll} & \\ 1 & \infty \\ \vdots & \vdots \\ 0 & + \\ 0 & \vdots\end{array}\right|$
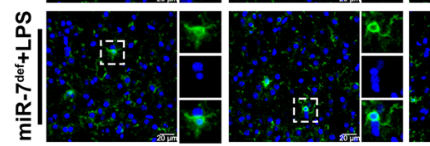

15?
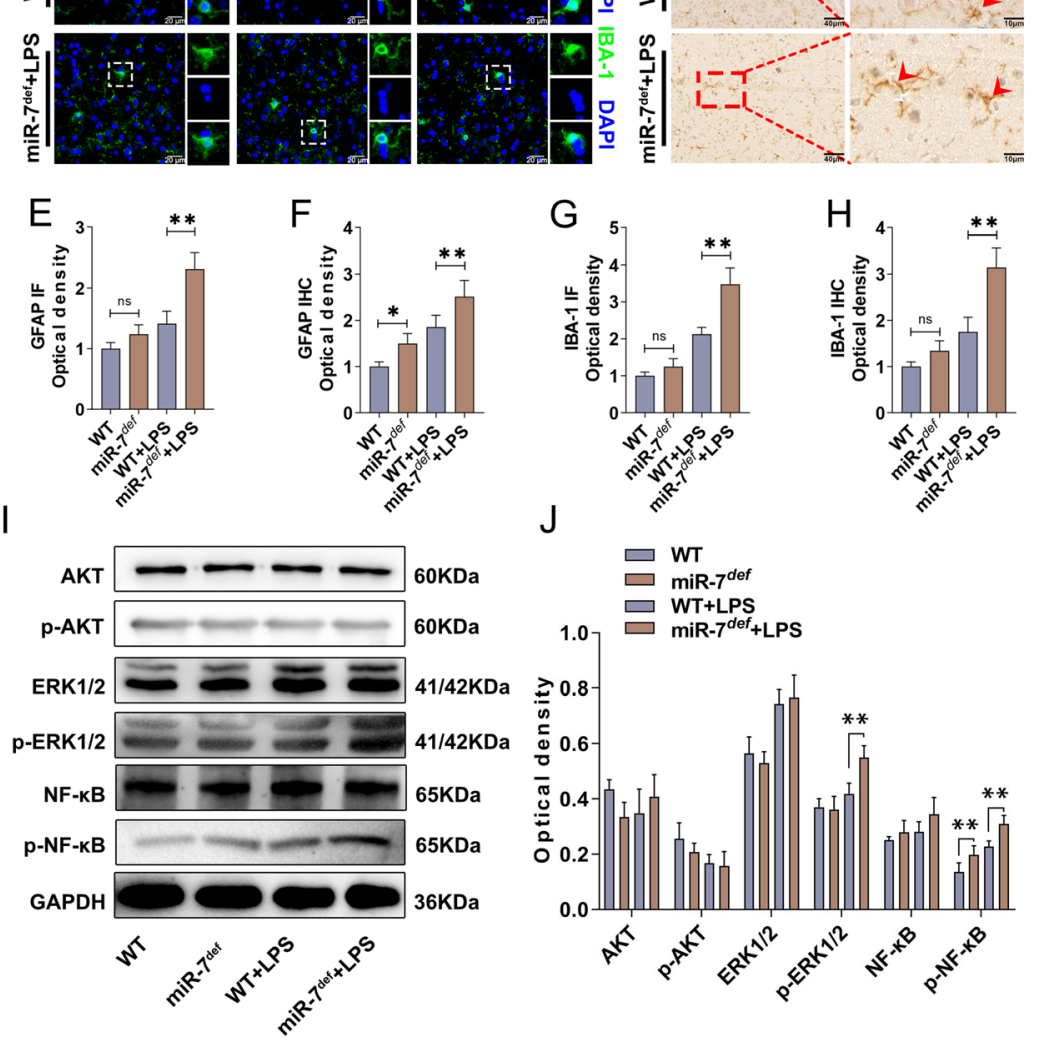

Fig. 3 (See legend on next page.) 
(See figure on previous page.)

Fig. 3 MiR-7 deficiency alters the composition of immune cells and the transduction of NF-KB, ERK signaling pathways in BTI model. WT mice and miR-7 ${ }^{\text {def }}$ mice were intraperitoneally injected with LPS ( $2.5 \mathrm{mg} / \mathrm{kg}$ of body weight) and control group with PBS. After $12 \mathrm{~h}, \mathbf{a}-\mathbf{h}$ the number of astrocytes in hippocampus and microglia in cerebral cortex were analyzed by IF and IHC and calculated $\left(n=3\right.$, one-way ANOVA, $\left.{ }^{* *} P<0.01\right)$. $\mathbf{i}, \mathbf{j}$ The protein levels of AKT, phos-AKT, ERK1/2, phos-ERK1/2, NF-KB, and phos- NF-KB in brain tissue were analyzed by Western blot assay and calculated, respectively $\left(n=3\right.$, one-way ANOVA, $\left.{ }^{* *} P<0.01\right)$

secondary antibody of Alexa Fluor 488-conjugated Goat Anti-Rabbit IgG (1:500; Invitrogen), Cy3-labeled Goat Anti-Rabbit IgG ( $\mathrm{H}+\mathrm{L})(1: 500$; Beyotime) in the dark, at room temperature for $1 \mathrm{~h}$. Finally, sections were mounted with Slow Fade Gold Antifade Reagent with DAPI, and examination by fluorescence microscopy (Zeiss Axioplan 2).

\section{Gene expression microarray}

Global gene expression array data was available in the National Center for Biotechnology Information (NCBI) Gene Expression Omnibus (GEO) under accession number GEO: GSE122114.

\section{Nissl staining}

Brain tissue was fixed in $4 \%(\mathrm{w} / \mathrm{v})$ paraformaldehyde, paraffin-embedded, and sliced in sections of $4-\mu \mathrm{m}$ thickness. After dewaxing in xylene and rehydration through graded ethanol, the sections were hydrated in $1 \%(\mathrm{w} / \mathrm{v})$ toluidine blue at $50{ }^{\circ} \mathrm{C}$ for $20 \mathrm{~min}$. Two investigators blinded to group assignments analyzed the samples and determined the level of brain inflammation injury. All brain fields at original magnification $\times 100$ and $\times 400$ were examined for each example.

\section{Statistical analyses}

Data were expressed as the mean \pm SEM from at least three independent experiments. Statistical analysis was performed by unpaired Student's test (two-tailed) for two groups Student's $t$ test or one-way analysis of variance (ANOVA) with Bonferroni's correction for three or more groups to evaluate statistical significance using GraphPad Prism 7.0 software. $P<0.05$ was considered statistically significant.

\section{Results}

\section{MiR-7 is upregulated in brain tissue of LPS-induced murine BTI model}

We first tested the expression level of miR-7 in BTI model. As shown in Fig. 1 a and b, inflammatory cell infiltration and hemorrhage foci were observed in brain tissue of murine BTI model. Moreover, the relative expression levels of inflammatory cytokines IL-1 $\beta$, IL-6, TNF- $\alpha$, and TGF- $\beta$ in brain tissue also increased significantly (Fig. $1 \mathrm{c}-\mathrm{f}, P<0.05$ ), indicating BTI model was successfully constructed [24]. As shown in Fig. 1 g, Real-time PCR assay showed that the relative expression levels of pre-miR-7-1 and pre-miR-7-2 increased obviously, especially for pre-miR-7-2. Next, we further determined the expression of pre-miR-7-2 in brain tissue by FISH assay and obtained similar results (Fig. 1h). Importantly, the relative expression level of mature miR-7 also increased significantly in brain tissue in murine BTI model (Fig. 1i, $P<0.05$ ). These results demonstrate that miR-7 is upregulated in brain tissue in BTI model.

\section{MiR-7 deficiency aggravates the pathology of BTI}

Next, we further investigated the potential role of miR-7 in the pathology of BTI. As shown in Fig. 2 a and b, the expression level of miR-7 significantly decreased in the brain tissue of miR-7 $7^{d e f}$ mice, which was consistent with our previous work [23]. Importantly, compared with WT BTI model, the number of inflammatory cells and hemorrhage foci increased obviously the brain tissue of miR-7 ${ }^{\text {def }}$ BTI model (Fig. 2c). Real-time PCR analysis further showed that the expression levels of proinflammatory factor IL-1 $\beta$, IL-6, and TNF- $\alpha$ in brain tissue also increased significantly in miR- $7^{\text {def }}$ BTI model (Fig. $2 \mathrm{~d}, \mathrm{f}, \mathrm{h}, P<0.05$ ). By contrast, the expression level of anti-inflammatory factor TGF- $\beta$ decreased noticeably (Fig. 2j, $P<0.05$ ). Meanwhile, similar results were obtained by ELISA assay (Fig. 2e, g, i, k, $P<0.05$ ). These data indicate that miR-7 deficiency aggravates the pathology of BTI.

It is well known that astrocytes and microglia play an important role in brain inflammation [28-30]. To further investigate the effect of miR-7 deficiency on the pathology of BTI, we observed the possible changes on astrocytes and microglia in brain tissue and found that the number of astrocytes and microglia were elevated in miR-7 ${ }^{\text {def }}$ BTI model (Fig. 3a-h, $P<0.05)$. Previous literatures have demonstrated that some signaling pathways, including AKT, ERK1/2, and $\mathrm{NF}-\mathrm{KB}$ signaling pathways, were involved in the development of inflammatory diseases [31-33]. Thus, to elucidate whether miR-7 deficiency resulted in the change on these signaling pathways, the expression levels of AKT, phos-AKT, ERK1/2, phos-ERK1/2, as well as NF- $\kappa B$ and phos-NF- $\kappa B$, were analyzed, respectively. As shown in Fig. $3 \mathrm{i}$ and j, compared with those in WT BTI model, the expression levels of phos-NF- $\mathrm{KB}$ and phos-ERK1/2 increased significantly in miR-7 $^{\text {def }}$ BTI model $(P<0.05)$. These results 


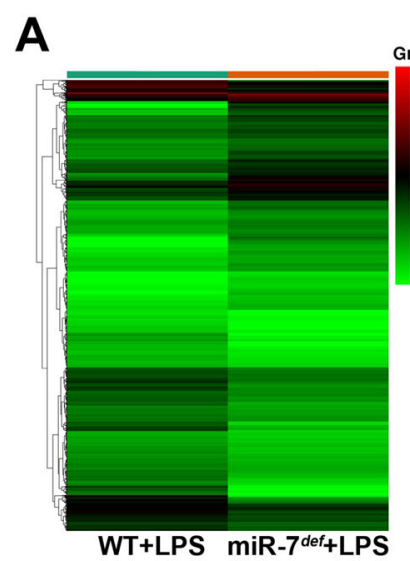

D

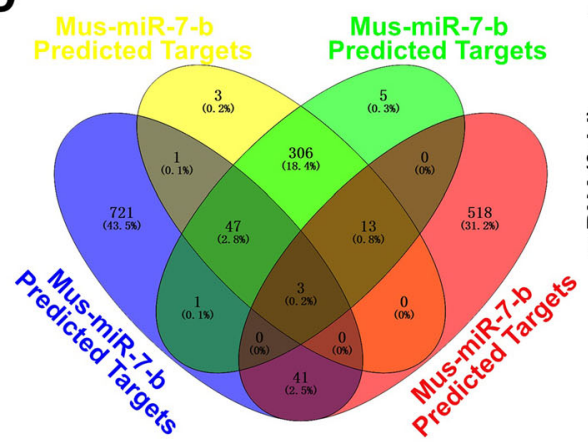

$\mathbf{F}$
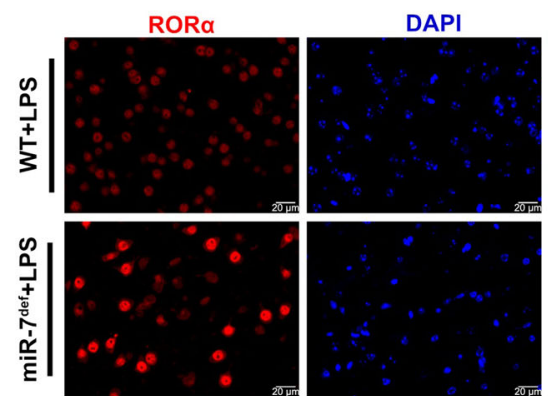

H

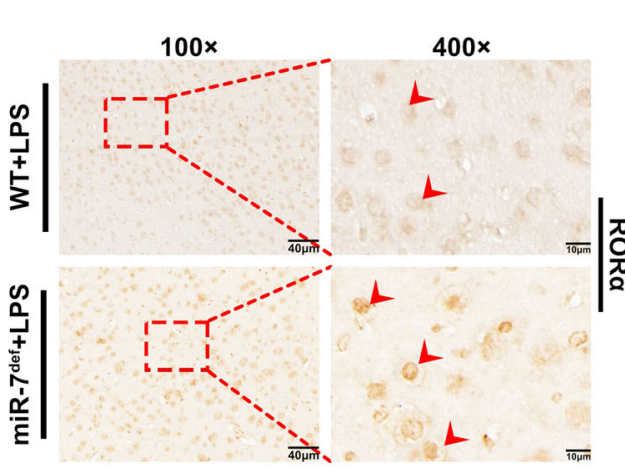

E
B pearson correlation:0.8480 - up-regulation genes(576)

\section{C}

not differential expressed (12307)

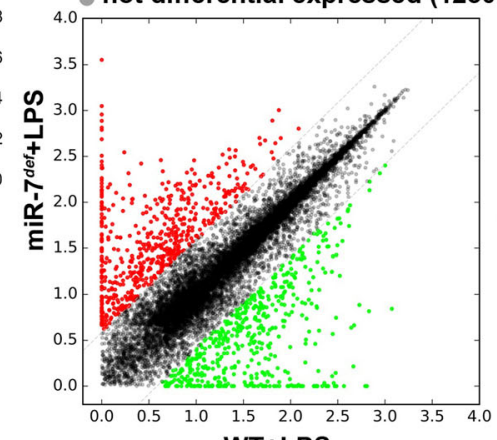

WT+LPS
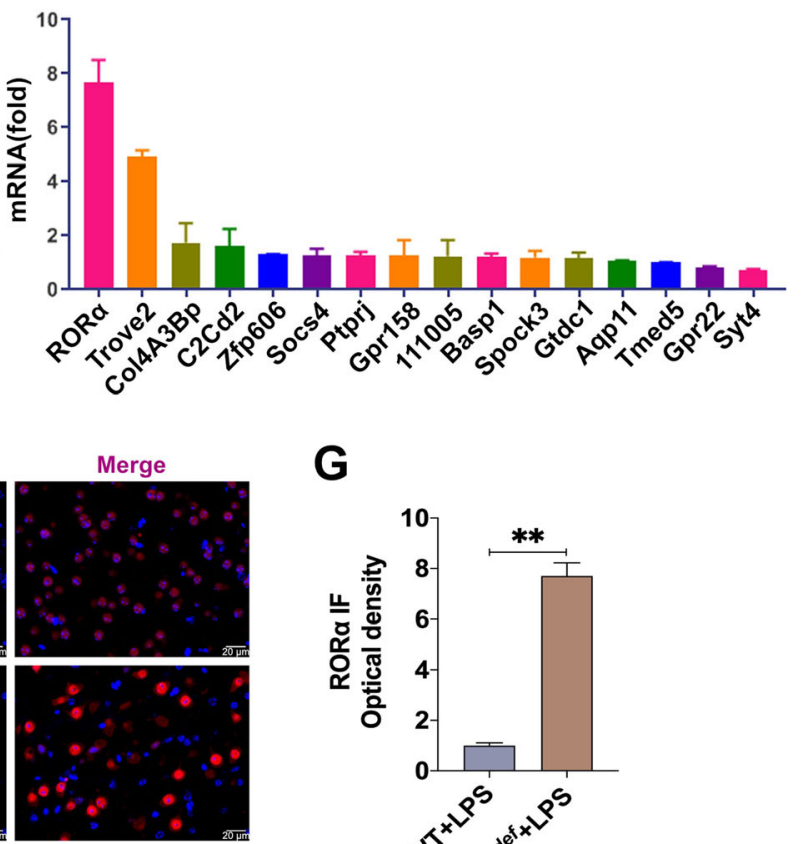

G

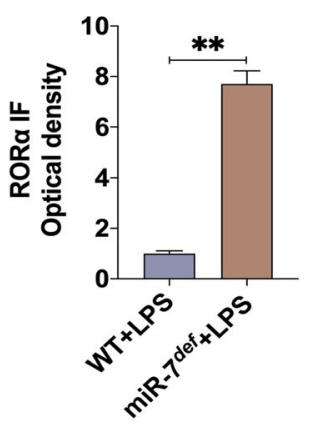

I

J

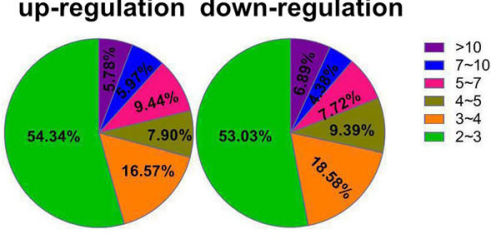
up-regulation down-regulation 
(See figure on previous page.)

Fig. 4 RORa is a novel target of miR-7 in BTI model. WT mice and miR-7 $7^{\text {def }}$ mice were intraperitoneally injected with LPS (2.5 mg/kg of body weight). After $12 \mathrm{~h}$, brain tissue was collected. The global gene expression was analyzed by CDNA chip array. a Heatmap and $\mathbf{b}$ scatter plot of gene expression. c The fold change and frequency. $\mathbf{d}$ Prediction of 16 target genes by using miRDB database (http://mirdb.org) and venn analysis. e The fold change of the potential target genes of miR-7 in the brain tissue was analyzed by real-time PCR assay and calculated $(n=3$, one-way ANOVA). $\mathbf{f}, \mathbf{g}$ The expression level of RORa was also determined by IF and $\mathbf{h}, \mathbf{i} \| \mathrm{HC}$ assay $(n=3$, one-way ANOVA). $\mathbf{j}$ Luciferase assay ( $n=$ 3, one-way ANOVA, ${ }^{* *} P<0.01$ )

indicate that miR-7 deficiency aggravates the pathology of BTI by altering the transduction of the NF$\kappa \mathrm{B}$ and ERK1/2 signaling pathways.

\section{RORa is a novel direct target of miR-7 in BTI model}

In order to explore the underlying mechanism of miR-7 deficiency on the pathology of BTI, we analyzed the global gene expression profile in brain tissue of BTI model (Fig. 4a, b). As shown in Fig. 4 c, given a twofold change (up and down) in differential expression as a cutoff, 519 genes were upregulated, and 479 genes were downregulated. Then, as shown in Fig. 4 d, we used miRDB database and Venn analysis software to screen out 16 upregulated genes, including RAR-related orphan receptor alpha (ROR $\alpha)$, TROVE domain family, member 2(Trove2), Collagen, type IV, alpha 3 (Goodpasture antigen) binding protein (Col4A3Bp), C2 domain-containing protein 2 (C2Cd2), Zinc finger protein 606 (ZFP606), suppressor of cytokine signaling (SOCS4), Receptor-type tyrosine-protein phosphatase eta (PTPRJ), G proteincoupled receptor 158 (GPR158), 111005, Brain abundant membrane attached signal protein 1(BASP1), sparc/ osteonectin, cwcv and kazal-like domains proteoglycan 3(SPOCK3), Glycosyltransferase-like domain-containing protein 1(GTDC1), Aquaporin11(Aqp11), transmembrane emp24 protein transport domain containing 5 (TMED5), G protein-coupled receptor22(GPR22), and Synaptotagmin-4 (Syt4), which were closely associated with inflammatory diseases according to previous literatures [34-37]. To further investigate the putative target of miR-7, we verified the expression levels of these 16 predicted target genes, respectively. Notably, in all predicted target genes of miR-7, ROR $\alpha$ was significantly upregulated more than eightfold in the brain tissue of miR$7^{\text {def }}$ BTI model compared with WT BTI model (Fig. 4e, $P<0.05)$. Furthermore, IF and IHC analysis also showed that the expression level of ROR $\alpha$ increased significantly in brain tissue of miR-7 $7^{\text {def }}$ BTI model (Fig. $4 \mathrm{f}-\mathrm{i}, P<$ 0.01 ). Finally, luciferase gene reporter assay showed that miR-7 could directly regulate ROR $\alpha$ expression (Fig. 4g). Collectively, these data demonstrate that $\mathrm{ROR} \alpha$ is a novel target of miR-7 in BTI model.

\section{RORa is essential for the development of BTI}

ROR $\alpha$ belongs to a member of the NR1 subfamily of nuclear hormone receptors. An increasing body of literature has documented that ROR $\alpha$ plays an important role in inflammatory reaction [38-40]. However, the possible role of ROR $\alpha$ in the pathology of BTI is still unknown. Then, we silenced the expression of ROR $\alpha$ by RNAi to observe the possible change on the pathology of BTI. As shown in Fig. 5 a and b, the relative expression level of ROR $\alpha$ reduced significantly in brain tissue from ROR $\alpha$-siRNA-treated group compared with control group $(P<0.05)$. Surprisingly, the number of inflammatory cells and vacuolar degeneration increased obviously in ROR $\alpha$-siRNA-treated group (Fig. 5c). Moreover, the mRNA expression levels of pro-inflammatory factor IL$1 \beta$, IL-6, and TNF- $\alpha$ in brain tissue also increased significantly (Fig. $5 \mathrm{~d}, P<0.05$ ). By contrast, the expression level of anti-inflammatory factor TGF- $\beta$ decreased noticeably (Fig. $5 \mathrm{~d}, P<0.05$ ). Meanwhile, similar results were also obtained by ELISA assay (Fig. $5 \mathrm{e}-\mathrm{h}, P<0.05$ ). IHC and IF assay further showed that the number of astrocytes and microglia elevated significantly in ROR $\alpha$ siRNA-treated group (Fig. 5i-p, $P<0.05$ ). Finally, we analyzed the possible change of AKT, ERK, and NF- $\mathrm{kB}$ signaling pathways and found that the levels of phos-NF$\kappa \mathrm{B}$ and phos-ERK1/2 in ROR $\alpha$-siRNA-treated group increased significantly (Fig. 5q, r; $P<0.05$ ). These results indicate that ROR $\alpha$ plays an important role in the pathology of BTI.

\section{Downregulation of RORa aggravates the pathology of miR-7 $^{\text {def }}$ BTI model}

To further explore the underlying role of $R O R \alpha$ in the effect of miR-7 deficiency on BTI, we silenced the expression of ROR $\alpha$ in miR $-7^{d e f}$ mice and then BTI model was constructed as in the above description. The number of inflammatory cells and nuclear fragments increased obviously in brain tissue in ROR $\alpha$-siRNAtreated group (Fig. 6a). Moreover, as shown in Fig. 6 b, the relative expression levels of pro-inflammatory factor TNF- $\alpha$, IL- $1 \beta$, and IL- 6 increased significantly in ROR $\alpha$ siRNA-treated group while anti-inflammatory factor TGF- $\beta$ decreased noticeably compared with control group $(P<0.05)$. Meanwhile, similar results were obtained by ELISA assay (Fig. $6 \mathrm{c}-\mathrm{f}, P<0.05$ ).

Furthermore, IHC and IF assay showed that the number of astrocytes and microglia were elevated significantly in ROR $\alpha$-siRNA-treated group (Fig. 6g-n). Finally, we analyzed the possible change of AKT, ERK, 


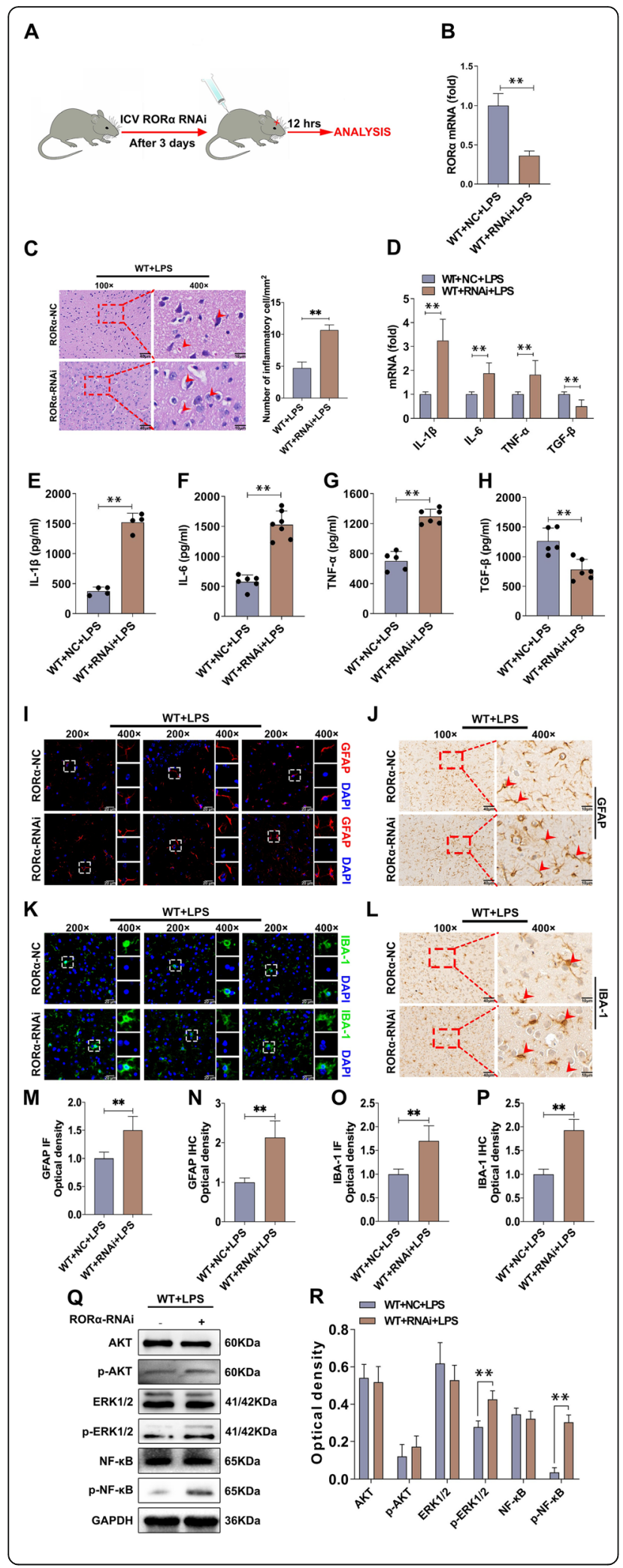

Fig. 5 Silence of RORa aggravates the pathology and alters the NF$K B$, ERK signaling pathways. a The schematic representation of the animal experiments. WT mice ( $n=6$ per group) were transfected with RORa RNAi or negative control (NC) RNAi through lateral ventricle. After 3 days, these mice were intraperitoneally injected with LPS ( $2.5 \mathrm{mg} / \mathrm{kg}$ of body weight). Twelve hours later, brain tissue was collected. $\mathbf{b}$ The expression level of RORa in brain tissue was analyzed by real-time PCR assay and calculated ( $n=6$ per group, $t$ test, $\left.{ }^{* *} P<0.01\right)$. c The pathology of brain tissue was observed by H\&E staining ( $n=3$ per group). Arrows in $\mathbf{c}$ indicate vacuolar degeneration. $\mathbf{d}$ The mRNA levels of cytokines (IL-1 $\beta, \mathrm{IL}-6$, TNF-a, and TGF- $\beta$ ) were analyzed by real-time PCR assay and calculated $\left(n=5\right.$, one-way ANOVA, $\left.{ }^{*} P<0.01\right)$. e- $\mathbf{h}$ The protein levels of cytokines were analyzed by ELISA assay and calculated ( $n=4$, oneway ANOVA, $\left.{ }^{* *} P<0.01\right)$. i- $\mathbf{p}$ The number of astrocytes and microglia were analyzed by IF and IHC and calculated, respectively ( $n=3$, oneway ANOVA, $\left.{ }^{* *} P<0.01\right)$. q, $\mathbf{r}$ The protein levels of AKT, phos-AKT, ERK1/2, phos-ERK1/2, NF-KB, and phos-NF-KB were analyzed by Western blot assay and calculated $(n=3$, one-way ANOVA, $\left.{ }^{*} P<0.05,{ }^{*} P<0.01\right)$

and NF- $\mathrm{kB}$ signaling pathways. As shown in Fig. $6 \mathrm{o}$ and $\mathrm{p}$, the protein levels of phos-NF- $\mathrm{kB}$ and phos-ERK1/2 in ROR $\alpha$-siRNA-treated group increased significantly $(P<$ $0.05)$. These results demonstrate that downregulation of ROR $\alpha$ exacerbates the effect of miR-7 deficiency on the pathology of BTI.

\section{RORa and miR-7 are co-expressed in neurons in BTI model}

Next, in order to further explore the connection between ROR $\alpha$ and miR-7 in pathology of BTI, we analyzed the expression of ROR $\alpha$ and miR-7 in neurons, microglia, and astrocytes, which are major cell populations in brain tissue in BTI model. Interestingly, double immunofluorescence labeling assay showed that ROR $\alpha$ was dominantly expressed in neurons of brain tissue (Fig. $7 a-c$ ). However, miR-7 expressed both in neurons and other cells (Fig. 7d). Importantly, in neurons, the expression level of ROR $\alpha$ increased obviously in miR-7 ${ }^{\text {def }}$ BTI model compared with WT BTI model (Fig. 7a), which was consistent with our above data.

Previous studies have shown that neurons are involved in the pathology of BTI [41-44]. And we found that ROR $\alpha$ and miR-7 were co-expressed in neurons of BTI model. Then, we further observed the possible change of neurons in brain tissue from BTI model. Data showed that, compared with WT group, the number of neuron cells did not change significantly in the brain tissue in WT BTI model group (Fig. 7e, f, $P>0.05$ ). However, we found that, compared with WT group, the number of Nissl bodies in neurons of WT BTI model group decreased obviously (Fig. 7g, h, $P<0.05$ ), which was consistent with previous literature [45]. Most importantly, compared with WT BTI model, the number of Nissl bodies in neurons decreased obviously in miR- $7^{\text {def }}$ BTI 


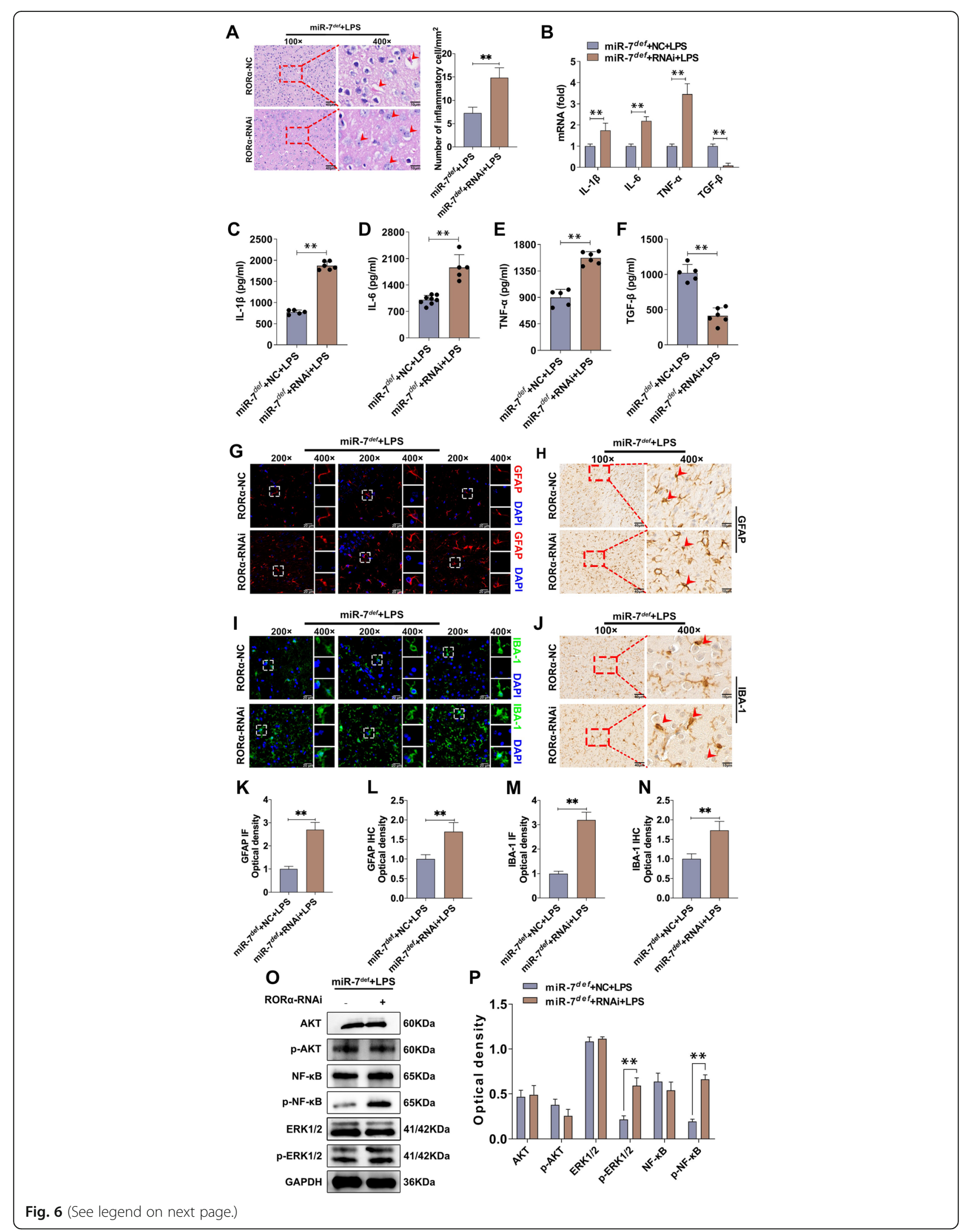


(See figure on previous page.)

Fig. 6 Silence of RORa aggravates the pathology of miR- $7^{\text {def }}$ BTI mice. MiR- $7^{\text {def }}$ mice ( $n=6$ per group) were transfected with RORa RNAi or NC RNAi through lateral ventricle. After 3 days, these mice were intraperitoneally injected with LPS ( $2.5 \mathrm{mg} / \mathrm{kg}$ of body weight). Twelve hours later, brain tissue was collected. $\mathbf{a}$ The pathology was observed by H\&E ( $n=3$ per group). Arrows in $\mathbf{c}$ indicate nuclear fragments. $\mathbf{b}$ The mRNA levels of cytokines (IL-1 $\beta$, IL-6, TNF- $a$, and TGF- $\beta$ ) were analyzed by real-time PCR assay and calculated $\left(n=6\right.$, one-way ANOVA, $\left.{ }^{* *} P<0.01\right)$. c-f The protein levels of cytokines were determined by ELISA assay and calculated $\left(n=5\right.$, one-way ANOVA, $\left.{ }^{* *} P<0.01\right)$. $\mathbf{g}-\mathbf{n}$ The number of astrocytes in hippocampus and microglia in cerebral cortex were analyzed by IF and IHC $\left(n=3\right.$, one-way ANOVA, $\left.{ }^{* *} P<0.01\right)$. $\mathbf{0}, \mathbf{p}$ The protein levels of signaling molecules including AKT, phos-AKT, ERK1/2, phos-ERK1/2, NF-KB, and phos-NF-KB in brain tissue were analyzed by Western blot assay and calculated $\left(n=3\right.$, one-way ANOVA, $\left.{ }^{*} P<0.01\right)$

model (Fig. $7 \mathrm{~g}, \mathrm{~h}, P<0.05$ ), indicating that miR-7 deficiency might impair the physiologic function of neurons.

\section{RORa synergizes with miR-7 to control the inflammatory reaction of neuronal cells in vitro}

Finally, in order to explore the role of $\operatorname{ROR} \alpha$ and miR-7 in inflammatory reaction of neurons, we observe the expression of ROR $\alpha$ and miR-7 in neuronal cells in response to LPS stimulation. Data showed that, compared with that in control group, the expression level of ROR $\alpha$ increased significantly in neuronal cells in miR-7 inhibitor-transfected group (Fig. 8a, $P<0.05)$. Importantly, we found that compared with that in LPS-treated group, the expression level of ROR $\alpha$ increased dramatically in LPS-treated miR-7 inhibitor-transfected group (Fig. 8a, $P<0.05$ ), which was consistent with our above data. Furthermore, we found that, after LPS stimulation, the expression of miR-7 in neuronal cells increased rapidly to the peak at $6 \mathrm{~h}$ and then gradually decreased (Fig. 8b), while the expression of ROR $\alpha$ decreased significantly at $6 \mathrm{~h}$ and then steadily increased, displaying a contrary expression pattern to miR-7 (Fig. 8b).

Next, we detected the production of inflammatory cytokines in neuronal cells in response to LPS stimulation and found that, as shown in Fig. $8 \mathrm{c}$, the expression levels of pro-inflammatory factor TNF- $\alpha$, IL-1 $\beta$, and IL- 6 increased significantly in ROR $\alpha$-RNAi-transfected group compared with control group $(p<0.01)$. As expected, compared with those in ROR $\alpha$-RNAi-transfected group, the expression levels of pro-inflammatory factor TNF- $\alpha$, IL- $1 \beta$, and IL-6 increased obviously in ROR $\alpha$-RNAi plus miR-7 inhibitor co-transfected group (Fig. 8c, $P<0.05$ ). Conversely, the expression level of anti-inflammatory factor TGF- $\beta$ decreased noticeably (Fig. $8 \mathrm{c}, P<0.05$ ). To verify these data, we detected the protein levels of these cytokines by ELISA assay and obtained similar results (Fig. $8 \mathrm{~d}-\mathrm{g}, P<0.05$ ). Finally, we also analyzed the possible change in AKT, ERK, and NF- $\mathrm{KB}$ signaling pathways. Data showed that the levels of phos-NF- $\mathrm{KB}$ and phos-ERK1/2 in ROR $\alpha$-RNAi-transfected group increased significantly compared with those in control group (Fig. 8h, i, $P<0.05$ ). Importantly, we found that the levels of phos-NF- $\mathrm{BB}$ and phos-ERK1/2 in ROR $\alpha-\mathrm{RNAi}$ plus miR-7 inhibitor co-transfected group increased significantly compared with those in ROR $\alpha$-RNAitransfected group (Fig. 8h, i, $P<0.05$ ). Together, these observations suggested that ROR $\alpha$ synergizes with miR-7 to control the inflammatory reaction of neuronal cells, which is closely correlated with the altered transduction of the NF-KB and ERK signaling pathways.

\section{Discussion}

Up to now, this is the first study to explore the potential role of miR-7 in the pathology of BTI. Herein, we found that the expression level of miR-7 increased significantly in LPS-induced BTI model. Furthermore, miR-7 deficiency could aggravate the pathology of BTI. Importantly, the expression level of ROR $\alpha$, a novel target of miR-7, was upregulated in brain tissue of BTI model with miR-7 deficiency. Unexpectedly, silence of ROR $\alpha$ remarkably exacerbated, but not alleviated, the pathology of brain tissue, as well as promoted the transduction of NF-kB and ERK1/2 signaling pathways in BTI model with or without miR-7 deficiency. Finally, ROR $\alpha$ and miR-7 were dominantly co-expressed in neurons from BTI mice and synergistically controlled the inflammatory reaction of neuronal cells in response to LPS stimulation.

Recently, miR-7 has been reported to play an important role in regulating the biological process of various diseases [46, 47]. For instance, miR-7 is a tumor suppressor and increase cisplatin sensitivity of gastric cancer cells by targeting mTOR, indicating its potential application for the treatment of human gastric cancer in the future [48]. Moreover, miR-7 can regulate $\alpha$-synuclein expression and downregulation of miR-7 results in the loss of dopaminergic neuronal in the substantia nigra [49]. In our previous study, miR-7 can regulate the pathology of acute lung injury [23]. Herein, we extended these previous findings by demonstrating that miR-7 was upregulated in BTI model. Importantly, miR-7 deficiency could aggravate the pathology of brain tissue, indicating miR-7 was a novel negative intrinsic regulator in BTI. Similarly, Cao's study found that long noncoding RNA small nucleolar RNA host gene 1 promoted neuroinflammation in the pathogenesis of Parkinson's disease via modulating miR-7/NLRP3 pathway [18]. Zhang's study found that miR-7 inhibited the expression of 

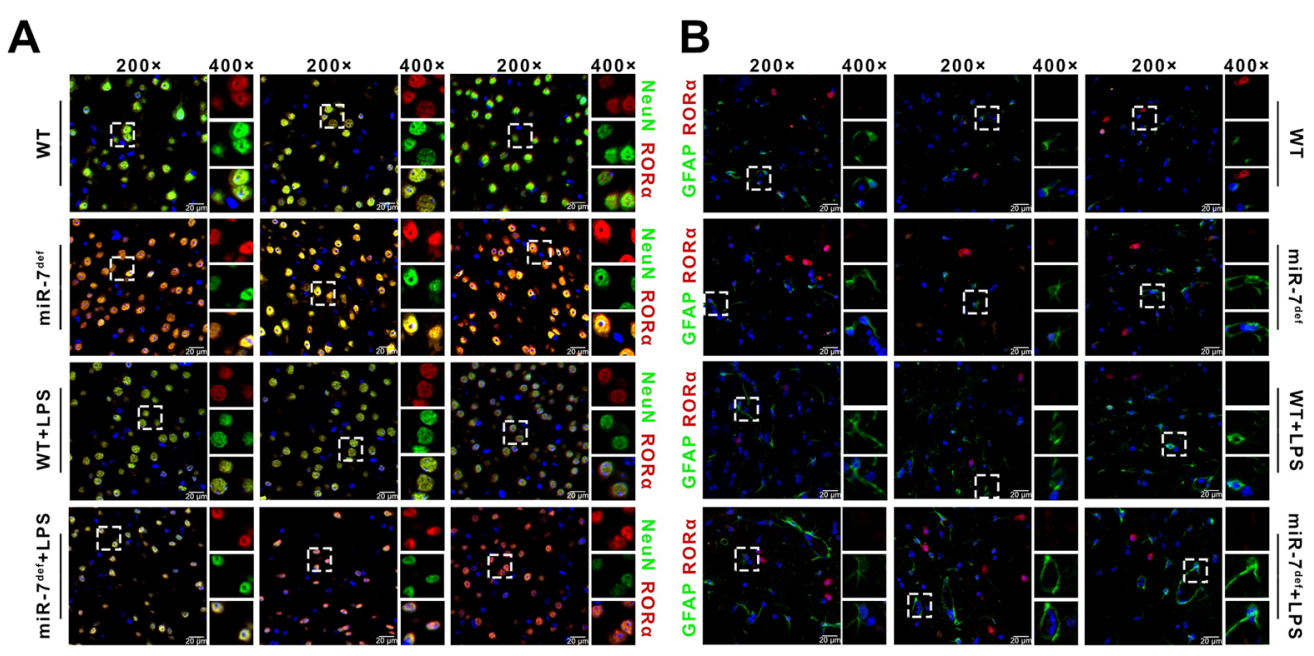

C

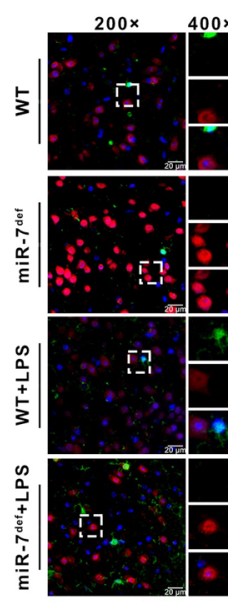

E
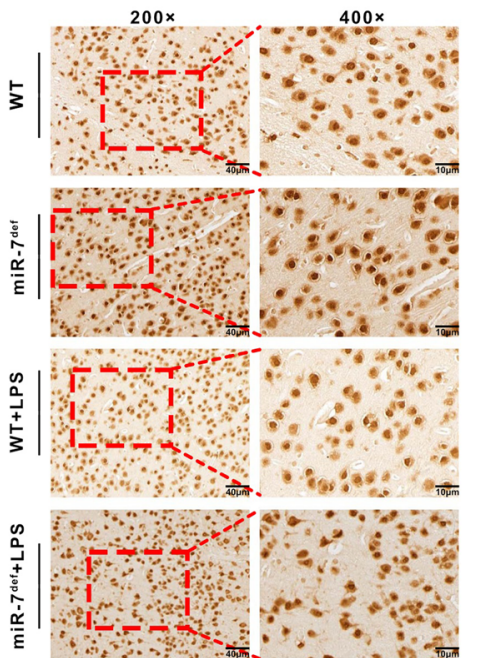

\section{D}

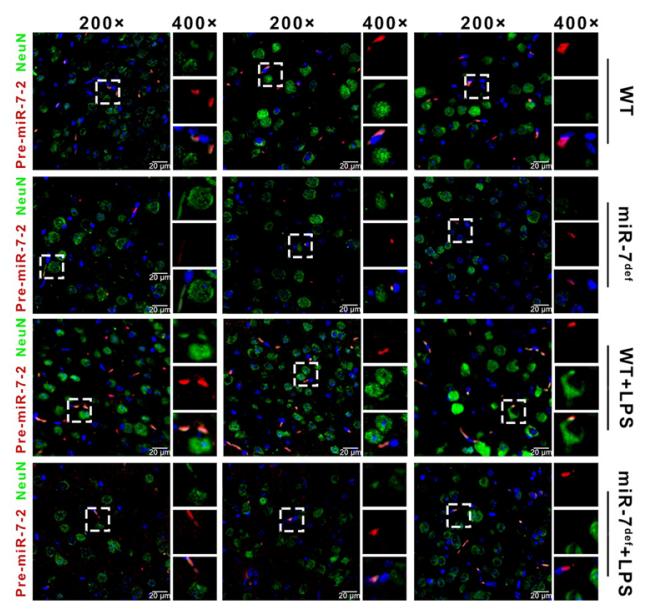

$\mathbf{F}$

G
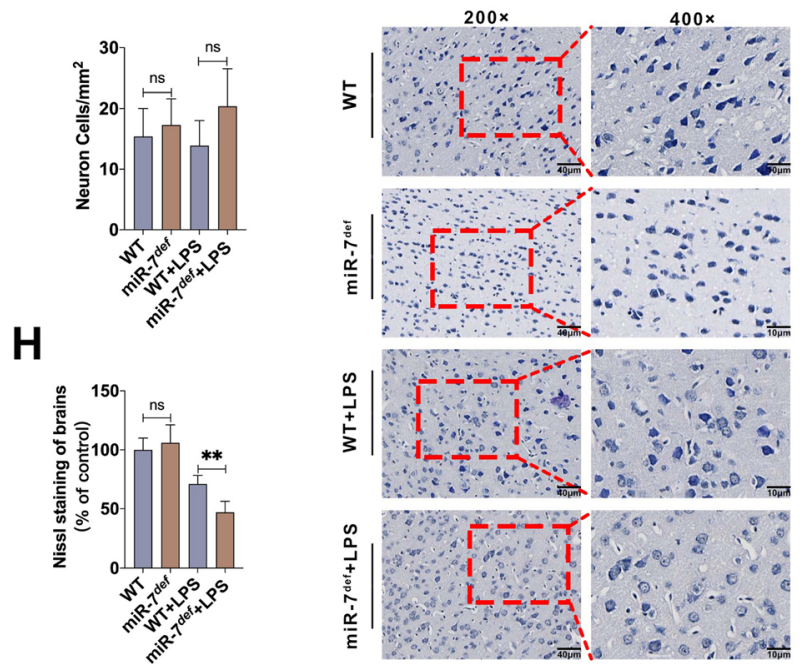

Fig. 7 (See legend on next page.) 
(See figure on previous page.)

Fig. 7 RORa and miR-7 were co-expression in the neuron. WT mice and miR-7 $7^{\text {def }}$ mice ( $n=6$ per group) were intraperitoneally injected with LPS ( $2.5 \mathrm{mg} / \mathrm{kg}$ of body weight) and control group with PBS, respectively. After $12 \mathrm{~h}$, a-c the colocated expression of RORa and NeuN, GFAP or IBA-1 were detected by double immunofluorescence labeling assay. $\mathbf{d}$ The expression of pre-miR-7-2 in neuron was analyzed by IF and FISH assay $(n=$ 6 per group). $\mathbf{e}-\mathbf{h}$ The change of neuron and Nissl bodies were detected by IHC and Nissl staining, respectively $(n=3$, one-way

ANOVA, $\left.{ }^{* *} P<0.01\right)$

TLR4 and reduced LPS-induced inflammatory response produced by microglial cells and then alleviated the inflammation in the brain of rats with cerebral hemorrhage [50]. It is well known that inflammation is a common pathological basis for various neurological diseases; therefore, our current findings might not only aid the understanding on the role of miR-7 in pathogenesis of BTI, but also provide a valuable clue for the development of therapeutic strategies against neurological diseases.

$R O R \alpha$ localizes on chromosome 9q22.2. Recent studies have shown that ROR $\alpha$ plays a vital role in the inhibition of the NF-kB signaling pathway transduction $[51,52]$. It is well known that NF- $\mathrm{BB}$ pathway is critical for the development of inflammatory response [53, 54], indicating that $R O R \alpha$ might be a suppressor in inflammation. Reyes-Gibby et al. found that ROR $\alpha$ might be a novel target gene by analyzing single nucleotide polymorphisms in patients with neuropathic pain, thereby providing a new therapeutic strategy for treatment and management of neuropathic pain [55]. In the present study, the expression level of ROR $\alpha$ increased in brain tissue in miR-7 deficiency BTI model mice. Importantly, the repression of ROR $\alpha$ could exacerbate the pathology of BTI, accompanied by elevated transduction of the NF- $\mathrm{BB}$ signaling pathway. Consistently, literature documented that ROR $\alpha$ could repress the transduction of NF- $\mathrm{kB}$ signaling pathway [56]. Therefore, combining these data demonstrated the important role of ROR $\alpha /$ $\mathrm{NF}-\mathrm{kB}$ axis in the pathology of BTI. Interestingly, we noticed that the repression of ROR $\alpha$ also altered the transduction of ERK1/2 signaling pathway. There is a growing body of evidence that suggests there is connection between NF- $\kappa B$ pathway and ERK1/2 pathway [5759]. Even though, the exact role of ROR $\alpha$ in ERK $1 / 2$ pathway still needs to be investigated in successive research work, which is important for the exploration of the pathogenesis of BTI and related inflammation brain diseases.

In biological events, synergism and antagonism effect are main forms of different genes in bringing into play biological function. Numerous studies have documented that the network among miRNA molecules and their target genes is complex and critical for the development of various diseases, in which miRNA usually controlled the expression of their targets $[60,61]$. However, whether there is synergy effect between miRNAs and target genes still remains unknown. In our study, we found that ROR $\alpha$ was a new target of miR-7 in BTI. Surprisingly, unlike previous reports that miRNAs exerted opposite biological function to their targets, repression of ROR $\alpha$ could aggravate, but not reverse, the pathology of BTI in the condition of miR-7 deficiency, indicating that ROR $\alpha$ exerted negative regulation on pathology of BTI in the absence of miR-7. Given the fact that ROR $\alpha$ expression was upregulated when miR-7 was deficient, then, our current study might raise a new network model in which miR-7 could control the pathology of BTI, synergistically with its target ROR $\alpha$. To this interesting phenomenon, we proposed it reflected the complexity of network among miRNA and their targets in the development of various diseases. Finally, it also would be pointed out that other targets, through which miR-7 controls the pathology of BTI, were not investigated in current study and remain to be elucidated in the future. Therefore, further investigation on the expression patterns of miR-7 and its different targets during the development of BTI is valuable for the validation of connections among miR-7 and its multiple targets in the pathology of BTI.

Accumulating evidence has shown that the change of biological function of neuronal cells is involved in the development of various brain diseases [62, 63]. Moreover, the relationship among neurons and other cells such as microglia and astrocytes is complex in the pathology of brain diseases [64, 65]. For instance, La et al. found that alpha-synuclein oligomers activating glial cells led to neuron damage and thus were emerging as crucial factors in the pathogenesis of synucleinopathies [66]. Wang et al. reported that HAPLN2 involved in the pathogenesis of schizophrenia by regulating the neuron migration and velocity of nerve conduction [67]. Similarly, Komura et al. found that amyl spheroids were accumulated mainly in the trans-golgi network of excitatory neuronal cells, causing the degeneration of adjacent NAK $\alpha 3$-expressing neurons in Alzheimer's disease [68]. In the present study, we found that the number of microglia and astrocytes were elevated in BTI model with miR-7 deficiency. Moreover, the physiologic function of neurons was also impaired. However, we revealed that ROR $\alpha$ was dominantly expressed in neurons, but not in microglia and astrocytes. Of note, miR-7 and ROR $\alpha$ were also co-expressed in neurons. Furthermore, in the absence of miR-7, inhibition of ROR $\alpha$ promoted the 


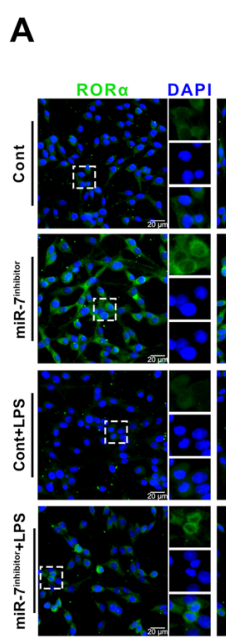

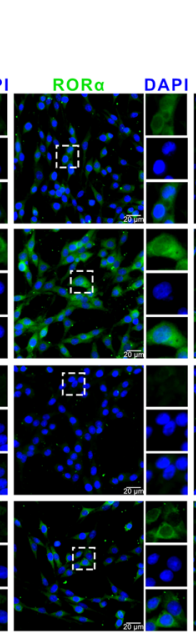

E

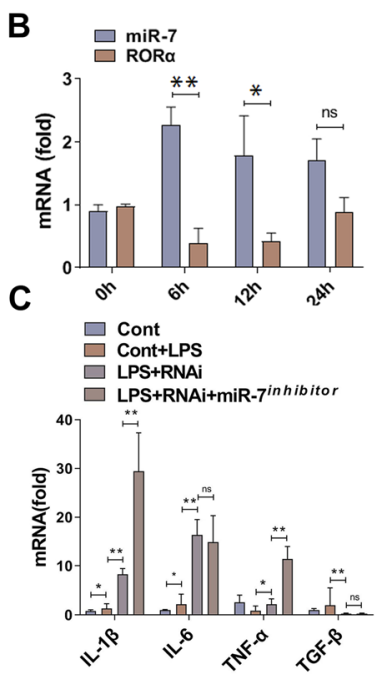

F

G

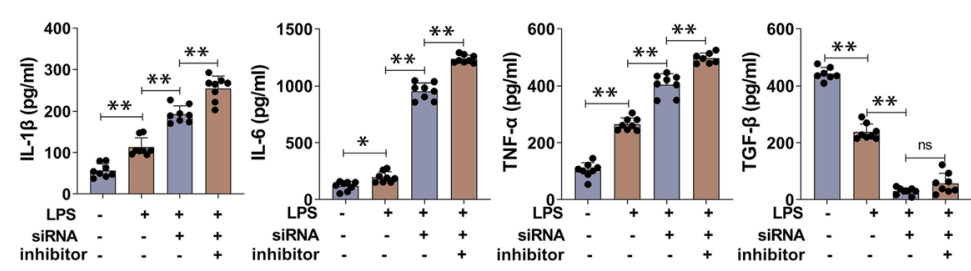

H

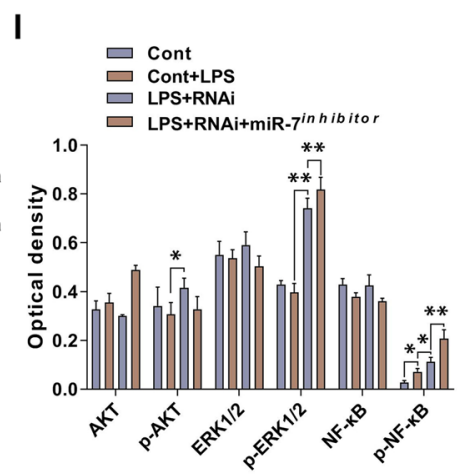

J

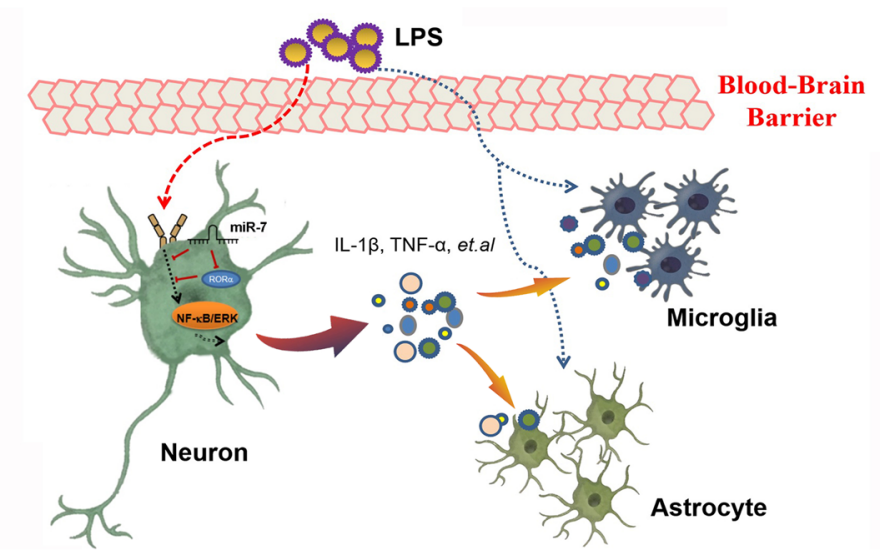

Fig. 8 (See legend on next page.) 
(See figure on previous page.)

Fig. 8 RORa synergizes with miR-7 to control the inflammatory reaction of neuronal cells in vitro. a Neuronal cell PC12 cells were stimulated by 100 ng/ $\mathrm{mL}$ LPS for $12 \mathrm{~h}$, the expression level of RORa was determined by double immunofluorescence labeling assay. $\mathbf{b}$ The expression levels of miR-7 and RORa in neuronal cells were determined by real-time PCR assay and calculated. Neuronal cells were infected with RORa RNAi or NC and then stimulated by 100 $\mathrm{ng} / \mathrm{mL}$ LPS for $12 \mathrm{~h}, \mathbf{c}-\mathbf{g}$ the expression levels of cytokines (IL-1 $\beta, I L-6$, TNF- $\alpha$, and TGF- $\beta$ ) were determined by real-time PCR assay and ELISA assay ( $n=7$, one-way ANOVA, $\left.{ }^{*} P<0.05,{ }^{* *} P<0.01\right)$. $\mathbf{h}$, i The protein levels of signaling molecules including AKT, phos-AKT, ERK1/2, phos-ERK1/2, NF-KB, and phos-NF-KB were determined by Western blot assay and calculated $\left(n=3\right.$, one-way ANOVA; ${ }^{*} P<0.05$, $\left.{ }^{*} P<0.01\right)$. j Schematic representation of the underlying mechanism of miR-7 and its target molecule RORa synergistically controlled the inflammatory reaction of neurons in response to LPS exposure, which subsequently affected the function of other cells including microglia and astrocytes and ultimately orchestrated the development of BTI

production of pro-inflammatory cytokines of neurons in response to LPS, which was closely correlated with the altered transduction of the NF- $\mathrm{kB}$ and ERK signaling pathways. In line with these finding, some studies have documented that LPS can stimulate neurons to secrete pro-inflammatory cytokines, which activate microglia, astrocytes, and other immune cells [69-71]. Therefore, our current data further support the important relationship among neurons and other cells in brain diseases, which might benefit the exploration on the cellular mechanism of the development of inflammation brain diseases.

\section{Conclusions}

Taken together, we found that miR-7 and its target molecule ROR $\alpha$ synergistically controlled the inflammatory reaction of neurons, which subsequently affected the function of other cells and ultimately orchestrated the pathology of BTI (Fig. 8j). Importantly, our findings might provide a new light on the network among miRNAs and their targets and aid the mechanistic understanding on BTI development, as well as the progression of new therapeutic strategies against clinical inflammatory brain diseases.

\section{Abbreviations}

3'-UTR: 3'-untranslated region; BTI: Brain tissue inflammation; def: Deficiency; miR-7: MicroRNA-7; RORa: RAR-related Orphan Receptor Alpha

\section{Acknowledgements}

We acknowledged CyagEen Biosciences Inc. for technical assistance with the generation of miR-7 ${ }^{\text {def }}$ mice and Zunyi Medical University laboratory Animal Center for providing housing and breeding places.

\section{Authors' contributions}

DY and JZ performed the experiments, analyzed the data, and wrote the paper. $\mathrm{HC}$ and MG performed the experiments and analyzed the data. HC, $M G, C C$, and $Y Z$ performed the experiments, LX conceived and designed the experiments, analyzed the data, and wrote the article. All authors reviewed the article. All authors read and approved the final manuscript.

\section{Funding}

This manuscript was supported by Program for New Century Excellent Talents in University, Ministry of Education of China (NCET-12-0661), National Natural Science Foundation of China (31760258), Program for High level innovative talents in Guizhou Province (QKH-RC-2016-4031), Program for Graduate Research Fund in Guizhou Province (KYJJ-2017002), Project of Guizhou Provincial Department of Science and Technology (QKH-RC-20181428), and Program for Excellent Young Talents of Zunyi Medical University (15ZY-001).
Availability of data and materials

All data are available upon request.

\section{Ethics approval and consent to participate}

All procedures were referred to the National Institutes of Health Guide for the Care and Use of Laboratory Animals and were approved by the Institutional Animal Care and Use Committees of Zunyi Medical University.

\section{Consent for publication}

Not applicable

\section{Competing interests}

The authors declare that the research was conducted in the absence of any commercial or financial relationships that could be construed as a potential conflict of interest.

\section{Author details}

'Special Key Laboratory of Gene Detection \& Therapy of Guizhou Province, Zunyi 563099, Guizhou, China. ${ }^{2}$ Department of Immunology, Zunyi Medical University, Zunyi 563099, Guizhou, China. ${ }^{3}$ Department of Medical Physics, Zunyi Medical University, Zunyi 563099, Guizhou, China.

Received: 19 August 2019 Accepted: 13 January 2020

Published online: 20 January 2020

\section{References}

1. Wang Q, He Q, Chen Y, Shao W, Yuan C, Wang Y. JNK-mediated microglial DICER degradation potentiates inflammatory responses to induce dopaminergic neuron loss. J Neuroinflammation. 2018;15:184.

2. Grimaldi A, Brighi C, Peruzzi G, Ragozzino D, Bonanni V, Limatola C, Ruocco G, Di Angelantonio S. Inflammation, neurodegeneration and protein aggregation in the retina as ocular biomarkers for Alzheimer's disease in the 3xTg-AD mouse model. Cell Death Dis. 2018;9:685.

3. Elo P, Tadayon S, Liljenback H, Teuho J, Kakela M, Koskensalo K, Saunavaara V, Virta J, Veres TZ, Kiviniemi A, Saraste A, Marjamaki P, Airas L, Jalkanen S, Roivainen A. Vascular adhesion protein-1 is actively involved in the development of inflammatory lesions in rat models of multiple sclerosis. J Neuroinflammation. 2018;15:128.

4. Sun X, Sun J, Shao X, Feng J, Yan J, Qin Y. Inhibition of microRNA-155 modulates endotoxin tolerance by upregulating suppressor of cytokine signaling 1 in microglia. Exp Ther Med. 2018;15:4709-16.

5. van Scheppingen J, Mills JD, Zimmer TS, Broekaart D, lori V, Bongaarts A, Anink JJ, lyer AM, Korotkov A, Jansen FE, van Hecke W, Spliet WG, van Rijen PC, Baayen JC, Vezzani A, van Vliet EA, Aronica E. miR147b: A novel key regulator of interleukin 1 beta-mediated inflammation in human astrocytes. Glia. 2018;66:1082-97.

6. Sun P, Liu DZ, Jickling GC, Sharp FR, Yin KJ. MicroRNA-based therapeutics in central nervous system injuries. J Cereb Blood Flow Metab. 2018;38:1125-48.

7. Xi T, Jin F, Zhu Y, Wang J, Tang L, Wang Y, Liebeskind DS, He Z. MicroRNA126-3p attenuates blood-brain barrier disruption, cerebral edema and neuronal injury following intracerebral hemorrhage by regulating PIK3R2 and Akt. Biochem Biophys Res Commun. 2017;494:144-51.

8. Yu G, Song Y, Xie C, Tao L, Wan F, Jiang L, Wang J, Tang J. MiR-142a-3p and miR-155-5p reduce methamphetamine-induced inflammation: role of the target protein Peli1. Toxicol Appl Pharmacol. 2019;370:145-53.

9. Lagos-Quintana M, Rauhut R, Lendeckel W, Tuschl T. Identification of novel genes coding for small expressed RNAs. Science. 2001;294:853-8. 
10. Zhao J, Wang K, Liao Z, Li Y, Yang H, Chen C, Zhou YA, Tao Y, Guo M, Ren T, Xu L. Promoter mutation of tumor suppressor microRNA-7 is associated with poor prognosis of lung cancer. Mol Clin Oncol. 2015;3:1329-36.

11. Lei L, Chen C, Zhao J, Wang H, Guo M, Zhou Y, Luo J, Zhang J, Xu L. Targeted expression of miR-7 operated by TTF-1 promoter inhibited the growth of human lung cancer through the NDUFA4 pathway. Mol Ther Nucleic Acids. 2017;6:183-97.

12. Fan X, Liu M, Tang H, Leng D, Hu S, Lu R, Wan W, Yuan S. MicroRNA-7 exerts antiangiogenic effect on colorectal cancer via ERK signaling. J Surg Res. 2019;240:48-59.

13. Ye T, Yang M, Huang D, Wang X, Xue B, Tian N, Xu X, Bao L, Hu H, Lv T, Huang Y. MicroRNA-7 as a potential therapeutic target for aberrant NF-kappaB-driven distant metastasis of gastric cancer. J Exp Clin Cancer Res. 2019;38:55.

14. Xu L, Wen Z, Zhou Y, Liu Z, Li Q, Fei G, Luo J, Ren T. MicroRNA-7-regulated TLR9 signaling-enhanced growth and metastatic potential of human lung cancer cells by altering the phosphoinositide-3-kinase, regulatory subunit 3/ Akt pathway. Mol Biol Cell. 2013;24:42-55.

15. Caygill EE, Brand AH. miR-7 buffers differentiation in the developing drosophila visual system. Cell Rep. 2017;20:1255-61.

16. Horsham JL, Ganda C, Kalinowski FC, Brown RA, Epis MR, Leedman PJ. MicroRNA-7: a miRNA with expanding roles in development and disease. Int J Biochem Cell Biol. 2015;69:215-24.

17. Choudhury NR, de Lima AF, de Andres-Aguayo L, Graf T, Caceres JF, Rappsilber J, Michlewski G. Tissue-specific control of brain-enriched miR-7 biogenesis. Genes Dev. 2013;27:24-38.

18. Cao B, Wang T, Qu Q, Kang T, Yang Q. Long noncoding RNA SNHG1 promotes neuroinflammation in Parkinson's disease via regulating miR-7/ NLRP3 pathway. Neuroscience. 2018;388:118-27.

19. Sang Q, Liu X, Wang L, Qi L, Sun W, Wang W, Sun Y, Zhang H. CircSNCA downregulation by pramipexole treatment mediates cell apoptosis and autophagy in Parkinson's disease by targeting miR-7. Aging (Albany NY). 2018;10:1281-93.

20. Titze-de-Almeida R, Titze-de-Almeida SS. miR-7 replacement therapy in Parkinson's disease. Curr Gene Ther. 2018;18:143-53.

21. Chen $H$, Shalom-Feuerstein R, Riley J, Zhang SD, Tucci P, Agostini M, Aberdam D, Knight RA, Genchi G, Nicotera P, Melino G, Vasa-Nicotera M. miR-7 and miR-214 are specifically expressed during neuroblastoma differentiation, cortical development and embryonic stem cells differentiation, and control neurite outgrowth in vitro. Biochem Biophys Res Commun. 2010;394:921-7.

22. Kabaria S, Choi DC, Chaudhuri AD, Jain MR, Li H, Junn E. MicroRNA-7 activates Nrf2 pathway by targeting Keap1 expression. Free Radic Biol Med. 2015;89:548-56.

23. Zhao J, Chen C, Guo M, Tao Y, Cui P, Zhou Y, Qin N, Zheng J, Zhang J, Xu L. MicroRNA-7 deficiency ameliorates the pathologies of acute lung injury through elevating KLF4. Front Immunol. 2016;7:389.

24. Zhao J, Bi W, Xiao S, Lan X, Cheng X, Zhang J, Lu D, Wei W, Wang Y, Li H, Fu Y, Zhu L. Neuroinflammation induced by lipopolysaccharide causes cognitive impairment in mice. Sci Rep. 2019;9:5790.

25. Jiang Z, Chen CH, Chen YY, Han JY, Riley J, Zhou CM. Autophagic effect of programmed cell death 5 (PDCD5) after focal cerebral ischemic reperfusion injury in rats. Neurosci Lett. 2014;566:298-303.

26. Ni J, Wang X, Chen S, Liu H, Wang Y, Xu X, Cheng J, Jia J, Zhen X. MicroRNA let-7c-5p protects against cerebral ischemia injury via mechanisms involving the inhibition of microglia activation. Brain Behav Immun. 2015;49:75-85.

27. Chen $\mathrm{CH}$, Jiang Z, Yan JH, Yang L, Wang K, Chen YY, Han JY, Zhang JH, Zhou CM. The involvement of programmed cell death 5 (PDCD5) in the regulation of apoptosis in cerebral ischemia/reperfusion injury. CNS Neurosci Ther. 2013;19:566-76.

28. Navarro-Mabarak C, Mitre-Aguilar IB, Camacho-Carranza R, Arias C, ZentellaDehesa A, Espinosa-Aguirre JJ. Role of NF-kappaB in cytochrome P450 epoxygenases down-regulation during an inflammatory process in astrocytes. Neurochem Int. 2019;129:104499.

29. Golia MT, Poggini S, Alboni S, Garofalo S, Ciano AN, Viglione A, Ajmone-Cat MA, St-Pierre A, Brunello N, Limatola C, Branchi I, Maggi L. Interplay between inflammation and neural plasticity: both immune activation and suppression impair LTP and BDNF expression. Brain Behav Immun. 2019.

30. Lu Z, Zhang H, Zhang X, Gao Y, Yin ZQ. Lipoxin A4 delays the progression of retinal degeneration via the inhibition of microglial overactivation. Biochem Biophys Res Commun. 2019;516:900-6.

31. Chu H, Hao W, Cheng Z, Huang Y, Wang S, Shang J, Hou X, Meng Q, Zhang Q, Jia L, Zhou W, Wang P, Jia G, Zhu T, Wei X. Black carbon particles and ozone-oxidized black carbon particles induced lung damage in mice through an interleukin-33 dependent pathway. Sci Total Environ. 2018;644: 217-28.

32. Martin Al, AB G-SM, Priego T, Lopez-Calderon A. Formoterol treatment prevents the effects of endotoxin on muscle TNF/NF-kB, Akt/mTOR, and proteolytic pathways in a rat model. Role of IGF-I and miRNA 29b. Am J Physiol Endocrinol Metab. 2018;315:E705-705E714.

33. Dai W, Yan J, Chen G, Hu G, Zhou X, Zeng X. AQP4knockout alleviates the lipopolysaccharideinduced inflammatory response in astrocytes via SPHK1/ MAPKVAKT signaling. Int J Mol Med. 2018;42:1716-22.

34. O'Leime CS, Hoban AE, Hueston CM, Stilling R, Moloney G, Cryan JF, Nolan YM. The orphan nuclear receptor TLX regulates hippocampal transcriptome changes induced by IL-1beta. Brain Behav Immun. 2018; 70:268-79.

35. Chiadak JD, Arsenijevic T, Gregoire F, Bolaky N, Delforge V, Perret J, Delporte C. Involvement of JNK/NFkappaB signaling pathways in the lipopolysaccharide-induced modulation of aquaglyceroporin expression in 3T3-L1 cells differentiated into adipocytes. Int J Mol Sci. 2016;17.

36. Dave RK, Dinger ME, Andrew M, Askarian-Amiri M, Hume DA, Kellie S. Regulated expression of PTPRJ/CD148 and an antisense long noncoding RNA in macrophages by proinflammatory stimuli. PLoS One. 2013;8: e68306.

37. Clancy RM, Alvarez D, Komissarova E, Barrat FJ, Swartz J, Buyon JP. Ro60associated single-stranded RNA links inflammation with fetal cardiac fibrosis via ligation of TLRs: a novel pathway to autoimmune-associated heart block. J Immunol. 2010;184:2148-55.

38. Kadiri S, Auclair M, Capeau J, Antoine B. Depot-specific response of adipose tissue to diet-induced inflammation: the retinoid-related orphan receptor alpha (RORalpha) involved. Obesity (Silver Spring). 2017;25:1948-55.

39. Yang Y, Guan J, Shaikh AS, Liang Y, Sun L, Wang M, Li D, Qiu C, Li X. Histone scetyltransferase Mof affects the progression of DSS-induced colitis. Cell Physiol Biochem. 2018;47:2159-69.

40. Jetten AM, Takeda Y, Slominski A, Kang HS. Retinoic acid-related orphan receptor gamma (RORgamma): connecting sterol metabolism to regulation of the immune system and autoimmune disease. Curr Opin Toxicol. 2018:8:66-80.

41. Wang G, Zhou Y, Wang Y, Li D, Liu J, Zhang F. Age-associated dopaminergic neuron loss and midbrain glia cell phenotypic polarization. Neuroscience. 2019;415:89-96.

42. Mao R, Deng R, Wei Y, Han L, Meng Y, Xie W, Jia Z. LIMK1 and LIMK2 regulate cortical development through affecting neural progenitor cell proliferation and migration. Mol Brain. 2019;12:67.

43. Schirmer L, Velmeshev D, Holmqvist $S$, Kaufmann M, Werneburg S, Jung D, Vistnes S, Stockley JH, Young A, Steindel M, Tung B, Goyal N, Bhaduri A, Mayer S, Engler JB, Bayraktar OA, Franklin R, Haeussler M, Reynolds R, Schafer DP, Friese MA, Shiow LR, Kriegstein AR, Rowitch DH. Neuronal vulnerability and multilineage diversity in multiple sclerosis. Nature. 2019; 573:75-82.

44. Watts ME, Wu C, Rubin LL. Suppression of MAP 4K4 signaling ameliorates motor neuron degeneration in amyotrophic lateral sclerosis-molecular studies toward new therapeutics. J Exp Neurosci. 2019;13: 1179069519862798.

45. Zhang $X X$, Chen L, Liu JL, Ito $Y$, He J, Sun WJ. Neuroprotection of total steroid saponins from Dioscorea zingiberensis against transient focal cerebral ischemia-reperfusion injury in rats via anti-inflammatory and antiapoptotic effects. Planta Med. 2014;80:1597-604.

46. Xia J, Cao T, Ma C, Shi Y, Sun Y, Wang ZP, Ma J. miR-7 suppresses tumor progression by directly targeting MAP $3 \mathrm{~K} 9$ in pancreatic sancer. Mol Ther Nucleic Acids. 2018;13:121-32.

47. Zhao J, Tao Y, Zhou Y, Qin N, Chen C, Tian D, Xu L. MicroRNA-7: a promising new target in cancer therapy. Cancer Cell Int. 2015;15:103.

48. Xu N, Lian YJ, Dai X, Wang YJ. miR-7 increases cisplatin sensitivity of gastric cancer cells through suppressing mTOR. Technol Cancer Res Treat. 2017; 16(6)1022-1030.

49. McMillan KJ, Murray TK, Bengoa-Vergniory N, Cordero-Llana O, Cooper J, Buckley A, Wade-Martins R, Uney JB, O'Neill MJ, Wong LF, Caldwell MA. Loss of MicroRNA-7 regulation leads to alpha-Synuclein accumulation and dopaminergic neuronal loss in vivo. Mol Ther. 2017;25:2404-14.

50. Zhang XD, Fan QY, Qiu Z, Chen S. MiR-7 alleviates secondary inflammatory response of microglia caused by cerebral hemorrhage through inhibiting TLR4 expression. Eur Rev Med Pharmacol Sci. 2018;22:5597-604. 
51. Wang Q, Lv C, Sun Y, Han X, Wang S, Mao Z, Xin Y, Zhang B. The role of alpha-lipoic acid in the pathomechanism of acute ischemic stroke. Cell Physiol Biochem. 2018;48:42-53.

52. Kim ME, Park PR, Na JY, Jung I, Cho JH, Lee JS. Anti-neuroinflammatory effects of galangin in LPS-stimulated BV-2 microglia through regulation of IL-1 beta production and the NF-kappaB signaling pathways. Mol Cell Biochem. 2019;451:145-53.

53. Voet S, Mc GC, Hagemeyer N, Martens A, Schroeder A, Wieghofer P, Daems C, Staszewski O, Vande WL, Jordao M, Sze M, Vikkula HK, Demeestere D, Van Imschoot G, Scott CL, Hoste E, Goncalves A, Guilliams M, Lippens S, Libert C, Vandenbroucke RE, Kim KW, Jung S, Callaerts-Vegh Z, Callaerts P, de Wit J, Lamkanfi M, Prinz M, van Loo G. A20 critically controls microglia activation and inhibits inflammasome-dependent neuroinflammation. Nat Commun. 2018;9:2036

54. Boudesco C, Verhoeyen E, Martin L, Chassagne-Clement C, Salmi L, Mhaidly R, Pangault C, Fest T, Ramla S, Jardin F, Wolz OO, Weber A, Garrido C, Jego G. HSP110 sustains chronic NF-kappaB signaling in activated B-cell diffuse large B-cell lymphoma through MyD88 stabilization. Blood. 2018;132:510-20.

55. Reyes-Gibby CC, Wang J, Yeung SJ, Chaftari P, Yu RK, Hanna EY, Shete S. Genome-wide association study identifies genes associated with neuropathy in patients with head and neck cancer. Sci Rep. 2018;8:8789.

56. Journiac N, Jolly S, Jarvis C, Gautheron V, Rogard M, Trembleau A, Blondeau JP, Mariani J, Vernet-der GB. The nuclear receptor ROR (alpha) exerts a bidirectional regulation of $\mathrm{IL}-6$ in resting and reactive astrocytes. Proc Natl Acad Sci U S A. 2009;106:21365-70.

57. Lifei T, Yiguo Q, Xinyu F, Lin R, Chunyan L, Wang J, Bo L. Angiotensinconverting enzyme 2 activator diminazene aceturate prevents lipopolysaccharide-induced inflammation by inhibiting MAPK and NF-KB pathways in human retinal pigment epithelium. J Neuroinflammation. 2018;13:35.

58. Taeyeop P, Huazhen C, Hee-Yong K. GPR110 (ADGRF1) mediates antiinflammatory effects of $\mathrm{N}$-docosahexaenoylethanolamine. J Neuroinflammation. 2019;16:225.

59. Liang W, Lin C, Liuqing Y, Li C, Guo P, Ping L, Wang W, Xin Z. Preactivation of Notch1 in remote ischemic preconditioning reduces cerebral ischemiareperfusion injury through crosstalk with the NF-kB pathway. J Neuroinflammation. 2019;16:181.

60. Wang X, Peng L, Gong X, Zhang X, Sun R, Du J. miR-423-5p inhibits osteosarcoma proliferation and invasion through directly targeting STMN1. Cell Physiol Biochem. 2018:50:2249-59.

61. Liu Y, Miao Y, Gao X, Wang YY, Wang H, Zheng YW, Zhao ZY. MicroRNA200a affects the proliferation of airway smooth muscle cells and airway remodeling by targeting FOXC1 via the PI3K/AKT signaling pathway in ovalbumin-induced asthmatic mice. Cell Physiol Biochem. 2018;50:2365-89.

62. Qiu C, Feng Z, Zheng L, Ma W. Selective modulation of neuronal firing by pulse stimulations with different frequencies in rat hippocampus. Biomed Eng Online. 2019;18:79.

63. Mclver EL, Atherton JF, Chu HY, Cosgrove KE, Kondapalli J, Wokosin D, Surmeier DJ, Bevan MD. Maladaptive downregulation of autonomous subthalamic nucleus activity following the loss of midbrain dopamine neurons. Cell Rep. 2019;28:992-1002 e4.

64. Gao L, Zhang Z, Lu J, Pei G. Mitochondria are dynamically transferring between human neural cells and Alexander disease-associated GFAP mutations impair the astrocytic transfer. Front Cell Neurosci. 2019;13:316.

65. Lu J, Huang H, Zeng Q, Zhang X, Xu M, Cai Y, Wang Q, Huang Y, Peng Q, Deng L. Hippocampal neuron loss and astrogliosis in medial temporal lobe epileptic patients with mental disorders. J Integr Neurosci. 2019;18:127-32.

66. La Vitola P, Balducci C, Cerovic M, Santamaria G, Brandi E, Grandi F, Caldinelli L, Colombo L, Morgese MG, Trabace L, Pollegioni L, Albani D, Forloni G. Alpha-synuclein oligomers impair memory through glial cell activation and via toll-like receptor 2. Brain Behav Immun. 2018;69:591-602.

67. Wang Q, Wang C, Ji B, Zhou J, Yang C, Chen J. Hapln2 in neurological diseases and its potential as therapeutic target. Front Aging Neurosci. 2019;11:60.

68. Komura H, Kakio S, Sasahara T, Arai Y, Takino N, Sato M, Satomura K, Ohnishi T, Nabeshima YI, Muramatsu SI, Kii I, Hoshi M. Alzheimer abeta assemblies accumulate in excitatory neurons upon proteasome inhibition and kill nearby NAKalpha3 neurons by secretion. iscience. 2019;13:452-77.

69. Aranda ML, Guerrieri D, Pinero G, Gonzalez FMF, Altschuler F, Dieguez HH, Keller SMI, Chianelli MS, Sande PH, Dorfman D, Rosenstein RE. Critical role of monocyte recruitment in optic nerve damage induced by experimental optic neuritis. Mol Neurobiol. 2019;56:7458-72.
70. Li L, Shu MQ, Chen J. CYLD deficiency exacerbates lipopolysaccharide (LPS)induced pyroptosis in astrocytes of mice with sepsis. Biochem Biophys Res Commun. 2019;514:1066-73.

71. Oliveira-Junior MS, Pereira EP, de Amorim V, Reis L, Do NRP, Da SV, Costa SL. Lupeol inhibits LPS-induced neuroinflammation in cerebellar cultures and induces neuroprotection associated to the modulation of astrocyte response and expression of neurotrophic and inflammatory factors. Int Immunopharmacol. 2019;70:302-12.

\section{Publisher's Note}

Springer Nature remains neutral with regard to jurisdictional claims in published maps and institutional affiliations.
Ready to submit your research? Choose BMC and benefit from:

- fast, convenient online submission

- thorough peer review by experienced researchers in your field

- rapid publication on acceptance

- support for research data, including large and complex data types

- gold Open Access which fosters wider collaboration and increased citations

- maximum visibility for your research: over $100 \mathrm{M}$ website views per year

At BMC, research is always in progress.

Learn more biomedcentral.com/submissions 